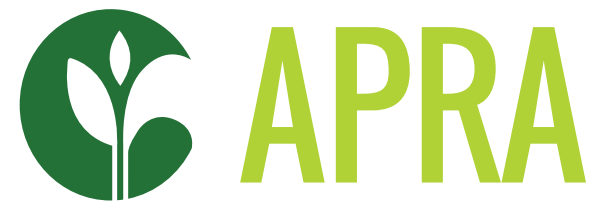

Agricultural Policy Research in Africa

\title{
THE POLITICAL ECONOMY OF THE RICE VALUE CHAIN IN ETHIOPIA: ACTORS, PERFORMANCE, AND DISCOURSES
}




\section{CONTENTS}

4

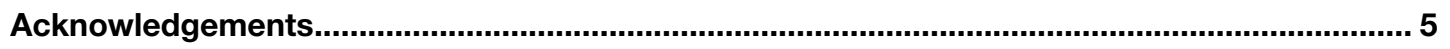

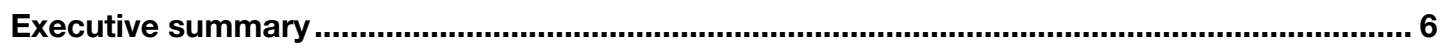

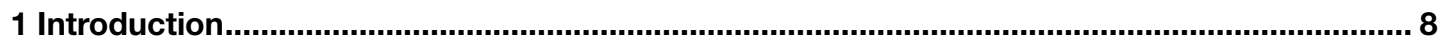



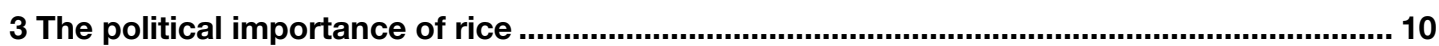

4 Overview and map of the rice value chain in Ethiopia: actors, performance,

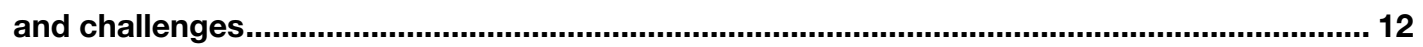

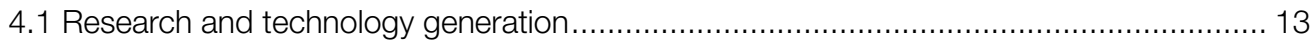

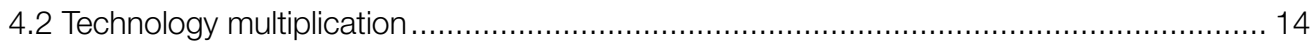



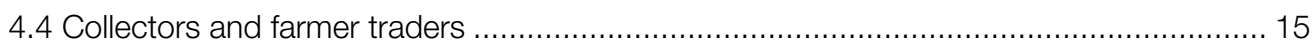

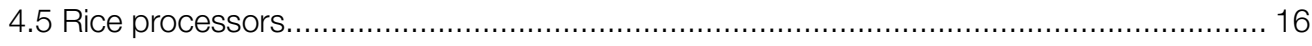

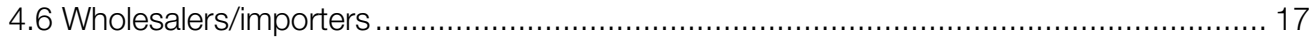

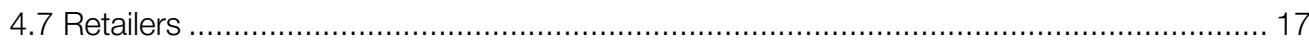





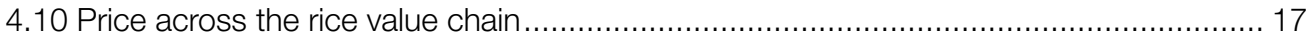

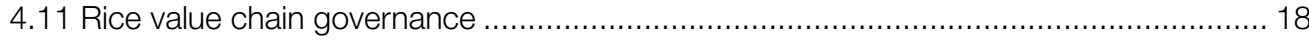

5 The role of development partners in the rice value chain ..................................................... 20

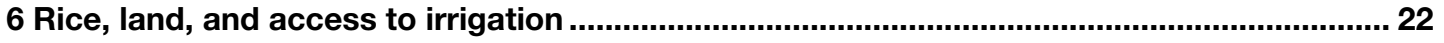

7 Rice and the rural labour market

8 Policy making within the rice value chain: discourses, debates, and policies/directives..... 25

8.1 Ensuring the competitiveness of domestic rice with imported rice:





8.3 The professionalisation and standardisation of domestic rice processing ..................... 26

8.4 Rice expansion and the implication for other crops and livestock ................................. 27

8.5 The role of rice in ensuring social inclusion and youth employment ................................ 27

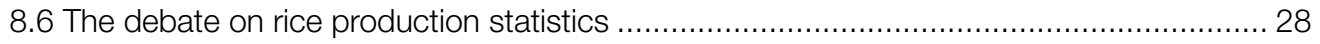

9 COVID-19: importance and impact on the rice value chain ...................................................... 29

9.1 The importance of COVID-19 public measures .................................................... 29

9.2 Response to and the impact of COVID-19 on rice value chain actors ........................... 29 
10 Conclusions

References 34

Endnotes

\section{Tables}

Table 4.1 The gender dimension of rice farmers, Fogera plain .................................... 14



Table 4.3 Role of rice processors in job creation by gender....................................... 16

Table 4.4 Prices of domestic rice across the value chain ......................................... 17

Table 5.1 Development partners and their role in rice sector development in Ethiopia ........... 23

Table 6.1 Access to irrigation by gender (\% of households) ..................................... 30

Table 9.1 Monthly average price trends of paddy and milled rice in Birr/kg

(2019 vs. 2020)

Figures

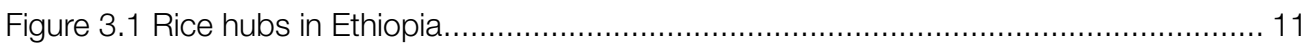

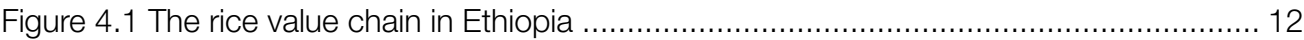

Figure 6.1 Trends in the number of youth and size of land allocated in Fogera district .......... 22






\section{ACRONYMS}

\begin{tabular}{ll} 
AgroBIG & Agro-Business Induced Growth \\
AgSS & agricultural sample survey \\
APRA & Agricultural Policy Research in Africa \\
ARARI & Amhara Regional Agricultural Research Institute \\
CARD & Coalition for African Rice Development \\
CSA & Central Statistical Agency \\
EA & enumeration area \\
EARO & Ethiopian Agricultural Research Organization \\
EIAR & Ethiopian Institute of Agricultural Research \\
FCDO & Foreign, Commonwealth \& Development Office \\
FGDs & focus group discussions \\
GARI & Gambella Agricultural Research Institute \\
IRRI & International Rice Research Institute \\
JICA & Japan International Cooperation Agency \\
JOCV & Japan Overseas Cooperation Volunteers \\
MoA & Ministry of Agriculture \\
NRRTC & National Rice Research and Training Center \\
OARI & Oromia Agricultural Research Institute \\
SoE & state of emergency \\
SoPARI & Somali Pastoral and Agro-pastoral Research Institute \\
TARI & Tigray Agricultural Research Institute \\
\hline
\end{tabular}




\section{ACKNOWLEDGEMENTS}

Dawit Alemu is an agricultural economist serving as a manager of the Bilateral Ethiopian-Netherlands Effort for Food, Income and Trade Partnership in Ethiopia. He is a member the Future Agricultures Consortium and country lead of the Agricultural Policy Research in Africa (APRA) programme in Ethiopia. Abebaw Asaye is a Researcher at the National Rice Research and Training Center (NRRTC) of the Ethiopian Institute of Agricultural Research (EIAR) and member of the APRA Programme in Ethiopia.

This research was conducted with funding from UK Aid (from the UK government Foreign, Commonwealth \& Development Office - FCDO, formerly the Department for International Development). The opinions are the authors and do not necessarily reflect the views or policies of the UK government or FCDO. 
This paper examines the political economy of the rice value chain in Ethiopia, covering the trends since the introduction of rice to the country in the early 1970s. It aims to identify the key challenges that have contributed to the poor performance of Ethiopia's rice sector and highlight approaches to successfully promote the commercialisation of the rice value chain. The paper uses a qualitative approach in analysing the secondary and primary data generated from different value chain actors and secondary data sources. The research examines the roles of rice value chain actors and their interests; the rules, regulations, and policies governing the rice value chain; the political importance of rice in Ethiopia; and the structure, agency, and intersectionality of the rice value chain.

The introduction of rice to Ethiopia was strongly linked to the government's quest to ensure food security and the settlement programmes during the Derg regime, which moved people from famine-stricken areas to less populated areas and encouraged them to farm rice. This agenda has evolved to focus on ensuring selfsufficiency in rice production in response to the huge scale of rice imports (accounting for 76 per cent of total national rice consumption), which create a burden on the meagre foreign currency reserves.

The government's collaboration with the International Rice Research Institute (IRRI) and AfricaRice, as well as technical and financial support from development partners, mainly the Japan International Cooperation Agency (JICA), has played an important role in Ethiopia's national research system. With this support, Ethiopia's research system has managed to release 37 improved varieties of rice seed, along with recommended production practices. However, the availability of other rice related technologies is very limited. Rice production is dominated by smallholder farmers and the use of quality seed of the released varieties is very low. This is due to the limited participation of actors engaged in certified seed production in Ethiopia's rice research system.

Gender wise, data from the Fogera plain indicates that female farmers are, on average, less endowed in terms of household labour and land allocated for rice production. The average rice productivity levels achieved by female-headed households is also, on average, smaller than male-headed households.

Rice processors, who work closely with rural collectors and farmer traders, play a crucial role in marketing both paddy and milled rice, in addition to the processing services and job creation they provide. The data from Fogera plain indicates that about 10 per cent of processors are women. The relative importance of the key challenges identified by processors differs between female and male operators. However, the major challenges identified by all processors are the poor quality and inadequacy of paddy supply, the instability of electricity supply, and the lack of price incentives for quality rice products.

The commercialisation of rice has contributed to the emergence of rural labour and land markets. Fifty-two per cent of smallholder rice farmers fulfil their labour demand using hired labour. The same is true for rice processors, on average, a processor hires six casual labourers.

With the outbreak of the COVID-19 crisis, the operation of the rice value chain has been moderately changed. These changes are linked to the responses of the different value chain actors to the measures put in place by the Ethiopian government and governments of other countries from which Ethiopia imports rice, mainly India and Pakistan and, to some extent, Vietnam. With the start of the COVID-19 pandemic after the harvest from the 2018/19 rice production season, farmers' rice production processes were not affected too much. Rather, they have enjoyed higher prices, which have increased by 5.67 per cent on average every month from January to May 2020 and by 14.72 per cent compared to the average price during the whole fivemonth period in 2019. Rice processors have limited their processing service provision. Instead, processors have been purchasing paddy and storing it in private storehouses as paddy rice, waiting for higher prices.

Recognising the strategic importance of rice and expected challenges due to the COVID-19 pandemic, the Ministry of Agriculture (MoA) has designed intervention options to boost domestic production and productivity. These include the expansion of rice 
production in the lowlands of the country, where there is huge potential for irrigated agriculture. In this regard, the key areas currently debated are (i) how to enhance the role of smallholder rice farmers and commercial farms without destructive competition; (ii) how to modernise the rice processing industry to ensure competitiveness with imported rice; (iii) how to boost the contribution of the rice industry in the creation of job opportunities and women's empowerment; (iv) how to generate reliable national rice statistics for improved strategic decision making, mainly in relation to rice production, the area cultivated for rice, and the productivity achieved; and (v) how to ensure rice import substitutions.

The poor performance of the rice value chain along with the emerging/dynamic challenges facing the sector need due policy and development attention. Initiatives need to boost domestic production and productivity in a manner that exploits not only the existing agricultural potential, but also available human resources. 
The political economy of rice sector development in Ethiopia is highly associated with the quest to ensure food security in food insecure areas. It is also closely linked to the country's production potential and its associated compatibility for rice production, the national trend towards increased rice consumption, and international trends in support of rice sector development (Alemu, Tesfaye and Assaye 2018). Accordingly, rice has become one of the most rapidly growing food commodities in Ethiopia, in line with the situation in other African countries (Woperies et al. 2013).

In response to the 1970s famine in different parts of the country, the Derg regime introduced a settlement programme where people from famine-stricken areas were taken to less populated areas, mainly to Gambella, Illubabor, and Pawe (Alemu and Berhanu 2018). Following the resettlement programme, rice production was promoted among the resettled communities in recognition of its adaptability to these areas. After the fall of the Derg regime, the resettled communities continued to produce rice and the locals also adapted and began to engage in rice production.

Increasing demand for rice for domestic consumption has resulted in a considerable increase in rice imports. The growing demand for rice is mainly associated with its compatibility in domestic food recipes, increased urbanisation, and the adaption of rice based international dishes by Ethiopian households, restaurants, and hotels. A similar trend has been seen in other African countries, which has had considerable impact on international rice markets (Woperies et al. 2013). This drew international attention and resulted in the establishment of a continental initiative, the Coalition for African Rice Development (CARD), to promote the doubling of domestic rice production every ten years from 2008.

These trends, mainly in terms of the increased importance of rice both at national and continental level, have been instrumental for the development of the rice value chain. They have helped to engage different actors and inspired recognition of the rice value chain at the policy level with the development of a national rice sector development strategy.
The main purpose of this paper is to understand the underlying political economy dynamics of the rice value chain in Ethiopia, and how these can give insights on the drivers and constraints of agricultural commercialisation in the country. The paper considers national policies and region/location specific opportunities and challenges. It focuses on the policy process for the development of the rice value chain by examining the role of political constraints, which emerge due to conflicts of interests among the diverse actors engaged across the different value chain segments.

The paper explains the research methodology before providing an overview of the political importance of rice in Ethiopia. The next section discusses the actors engaged in the rice value chain, their performance, and the challenges they face. This is followed by an examination of the role of development partners in promoting the rice value chain and the contribution of rice in the rural labour market. The remaining sections document the discourses, debates, and associated policies and directives, followed by an overview of the impact of the COVID-19 pandemic on the value chain actors. The last section provides the conclusions of this research. 
A qualitative research approach was employed for eliciting data and information from different secondary and primary sources dealing with agricultural commercialisation in general, and rice commercialisation in particular, in Ethiopia. The secondary data sources in question comprise of pertinent research reports, policy and strategy documents, and grey literature. An examination of the policies and strategies that are currently at work was undertaken with a view towards establishing the extent to which rice commercialisation is taking place across the rice value chain.

The primary data was generated from 20 key informant interviews as well as four focus group discussions (FGDs) involving a total of 37 participants. Interviews and FGDs involved actors engaged in the different segments of the rice value chain, between March and September 2020. The interviews and FGDs were guided by a checklist prepared for each group of actors, including: officials and experts from the federal MoA (two respondents), Agricultural Transformation Agency (one), regional bureaus of agriculture (four), and zonal and district offices of agriculture (four); researchers from federal and regional agricultural research institutes (four); managers and experts from development partner organisations engaged in rice sector development (two); rice importers (two); rice processors (six); rice wholesalers/retailers including retail shops (five); a rice seed cooperative (one); an agricultural input dealer (one); and smallholder rice farmers (five).

The political economy analysis covered (i) the identification of key actors and their interests in the rice value chain, (ii) the political importance of the rice value chain along with the prevailing discourses, (iii) the existing policies and rules in relation to how they affect the value chain performance across the different value chain actors and social groups, and (iv) the political implication of the expansion of rice production to the production of other crops. 


\section{THE POLITICAL IMPORTANCE OF RICE}

The political importance of rice in Africa is growing, and there has been a parallel increase in domestic production as well as consumption. Over ten years (2000-2010), the area allocated for rice production in Africa has increased from about 7.6 million ha to about 10.5 million ha. During the same period, total rice production has increased from about 17.5 million $t$ to about 25.9 million $t$, with an average yield increase from about 2.3t/ha to about 2.5t/ha (GRiSP 2013). There has also been a considerable increase in rice consumption in Africa, where per capita rice consumption has increased from $18.4 \mathrm{~kg} /$ year in 2000 to $21.1 \mathrm{~kg} /$ year in 2009 . This increased consumption is associated with rapid population growth, increasing per capita consumption, and consumer preferences shifting towards premium rice as a result of increased urbanisation. Accordingly, African rice consumption is projected to reach nearly $35 \mathrm{Mt}$ of milled rice by 2025 , of which $12.6 \mathrm{Mt}$ will be imported at a cost of approximately US\$5.5 billion annually (Alemu and Thompson 2020; AfricaRice 2018; GRiSP 2013).

The political importance of rice in Ethiopia has followed the same pattern as other African countries, which stems from several advantages that rice provides and the challenges it poses. Rice's relatively high yields and suitability for the preparation of several national dishes (injera, genfo, and kita) and traditional liquors (Tela and Areki), compared to other cereals, are two advantages. In addition to its wider adaptability, which allows producers to exploit the available natural resources, especially in lowland areas (Ismail 2019; MoARD 2010). On the other hand, the huge increase in domestic demand, which has forced the country to import huge volumes of rice, has created a burden on Ethiopia's meagre foreign currency reserve and perpetuates the continued decline in the level of self-sufficiency in rice.

The country is endowed with large resources for expanding rice production. Recent estimates suggest that 5.6 million ha of land is highly suited to rice farming in rainfed ecosystems and 3.7 million ha in irrigated systems (MoARD 2010), while the land allocated for rice production currently is only about 63,000ha (CSA 2019). Of the total cultivable land, estimated at 50 million ha, less than one-third is currently cultivated nationally (about 15 million ha). Moreover, of the total irrigable land potential, estimated at 5.3 million ha, only 640,000ha is irrigated (Awulachew, Erkossa and Namara 2010). This implies the possible expansion of rice production can be implemented with limited replacement of the production of other crops and the current expansion trends in the seven national rice hubs provide such evidence (Alemu and Thompson 2020). These hubs are major production areas, where rice value chain actors, especially producers and processors, are found (Figure 3.1). The increased domestic demand and the stagnant trend in domestic production has resulted in the decline of rice self-sufficiency, from about 76 per cent in 2008 to 24 per cent in 2019 (Alemu and Thompson 2020). Reversing this trend demands boosting domestic production, not only through increased productivity but also area expansion.

The potential opportunities and challenges presented by rice production have been instrumental to the due attention given to rice in Ethiopia and the government's recognition of it as a 'millennium crop'. In recognition of the importance of rice, the government developed a National Rice Research and Development Strategy (2010-2019) in 2010 to guide the full exploitation of existing rice production potential and to address the challenges facing the sector (MoARD 2010). In ensuring the implementation of the strategy, the country's development plans have given due attention to the rice sector. For instance, the government's Growth and Transformation Plan II (2015-2020) included intervention targets in an effort to not only ensure rice self-sufficiency, but also for food security, poverty reduction, and to enhance farmers' income. Government interventions include (i) enhanced extension services and improved access to inputs, mainly certified seeds for improved rice varieties and fertiliser; (ii) an enhanced value chainbased approach to rice production, along with the promotion of cluster farming; and (iii) motivating private investors to start commercial, irrigated rice farming, mainly in lowland areas (MoA 2015). 
Figure 3.1 Rice hubs in Ethiopia



Source: Authors' own 


\section{OVERVIEW AND MAP OF THE RICE VALUE CHAIN IN ETHIOPIA: ACTORS, PERFORMANGE, AND GHALLENGES}

The introduction of rice in Ethiopia is strongly linked to the quest to address food insecurity and the associated public resettlement programmes. Accordingly, rice was introduced mainly in food insecure areas, like Fogera plain, and resettlement areas, like Chewaka and Gambella. The introduction was made through the support of development partners. For example, the successful introduction of rice in the Fogera plain in the late 1970s was made with the support of agricultural experts from North Korea, though there had been previous attempts to introduce rice since the 1950s (Tadesse 2019)

The increased political importance of rice has been highly associated with its revealed economic relevance. This is linked with (i) the demonstrated evidence of rice's success in addressing food insecurity, especially with the government resettlement programmes; (ii) the dramatic increase in the volume of imported rice that has created a huge burden on Ethiopia's meagre foreign currency reserves; (iii) the high potential for increased domestic production in the different rice agro-ecologies (lowland, upland, and irrigated areas); and (iv) the increased domestic demand associated with the compatibility of rice with national food recipes, mainly ingera.

The data for the year 2018, indicates that rice production in Ethiopia engaged about 162,000 smallholder farmers, covering 53,000ha of land and producing about 151,000t (CSA 2018). According to the Ethiopian Revenue and Customs Authority, Ethiopia's rice imports total 393,000t per year. This indicates that the extent of self-sufficiency in rice is only about 28 per cent. As a country fully dependent on the export of agricultural commodities for the generation of foreign currency, the huge burden that rice is creating on foreign currency reserves has made it a very important commodity in the debate related to import substitution.

With the increase in the importance of rice since its introduction to the country in the late 1970s, the type and composition of actors engaged in the rice value

Figure 4.1 The rice value chain in Ethiopia

\section{Rice value chain governance}

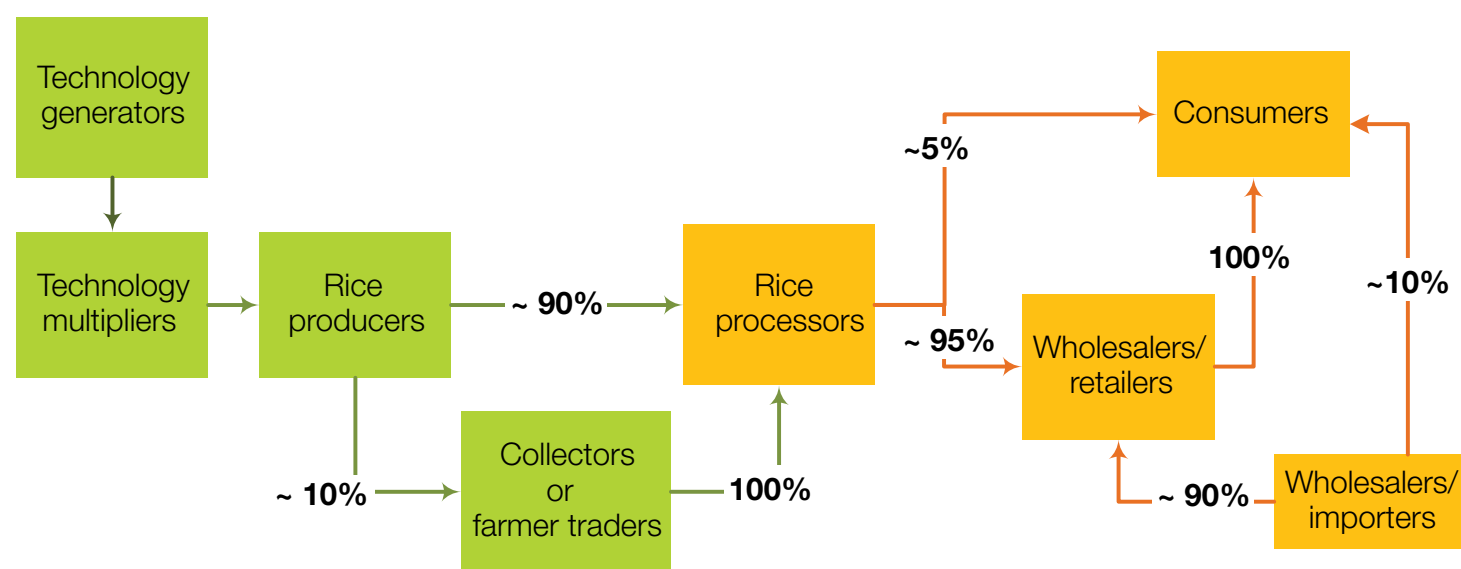

\section{Support service providers}

Paddy rice

Milled rice

Source: Authors' own 
chain has evolved considerably. As indicated in Figure 4.1, the key actors engaged in the rice value chain are those engaged in technology generation and multiplication, rice production, processing, marketing, and those that provide services and overall governance.

\subsection{Research and technology generation}

Formal rice technology generation in Ethiopia is linked with the establishment of the Pawe and Abobo research centres during the massive resettlement programme in the Pawe and Gambella areas in 1986. The research at Abobo was supported by Japan Overseas Cooperation Volunteers, while at Pawe, the research and production activities were supported through the Italian TanaBeles Project (Tadesse 2019). Though no formally released and registered rice varieties were produced, the research efforts at both Pawe and Abobo ensured wider demonstration of rice production practices, mainly to settlers.

Rice research in Fogera plain started in the 1980s through the technical support of North Korean experts, as part of the Ethio-Jigna Development Project. The North Korean team, composed of nine experts, were able to introduce and evaluate different rice genotypes in the Fogera plain, specifically by working together with the Jigna farmers' cooperative in Dera district and the Shaga farmers' cooperative in Fogera district. This was during the Derg regime, which had a very close relationship with the then 'Eastern Bloc' countries. The economic and political measures implemented during this regime were copied from those socialist countries. Accordingly, collective action, through the promotion of farmers' cooperatives, was the main intervention introduced to ensure rural transformation. As a result of the efforts of North Korean experts, a rice variety called $\mathrm{X}$-Jigna, was widely promoted. $\mathrm{X}$-jigna rice variety is still popular in the Fogera plain.

With the collapse of the Derg regime in 1991, the cooperatives stopped operating and rice producers from the resettlement areas were evacuated. This resulted in a considerable decline in rice research, extension services, and production activities, mainly in the Gambella, Pawe, and Fogera areas.

The revitalisation of agricultural research in the country was promoted by the Ethiopian People's Revolutionary Democratic Front regime, which came to power in 1991. As a result, the Adet and Pawe agricultural research centres were re-established under the then Institute of Agricultural Research in 1994. This was followed by the restructuring of the agricultural research system, which resulted in the establishment of the Ethiopian Agricultural Research Organization (EARO), now the Ethiopian Institute of Agricultural Research (EIAR) at the federal level and seven regional agricultural research institutes. Accordingly, Pawe research centre remained one of the EARO research centres and Adet moved to Amhara Regional Agricultural Research Institute (ARARI) in 1997. The national mandate for rice research coordination was initially given to Pawe, but it was moved to Adet research centre under ARARI in 2003. With the expansion of rice production in different parts of the country, a number of federal and regional research centres began to conduct rice research with an emphasis on adaptation trials.

The National Rice Research and Development Strategy of Ethiopia was launched in 2010 (MoARD 2010). One of this strategy's priorities was the strengthening of the National Rice Research Programme with the establishment of a fully-fledged rice research centre. Accordingly, a National Rice Research and Training Center (NRRTC) was established at Fogera in 2013 and the research facility was inaugurated in 2018.

The construction of the NRRTC was funded by the Japanese government and there is an ongoing technical cooperation project entitled EthioRice: 20152021, implemented by Japan International Cooperation Agency (JICA). EthioRice aims to make the NRRTC fully functional, both to undertake research and to provide training for all actors in the rice value chain. The key areas of support provided by the EthioRice project are human capacity building in terms of short- and longterm training, technical exchange visits abroad for researchers, the supply of required equipment and facilities, and the promotion of knowledge transfer by allocating Japanese experts for short and long-term periods (Shiratori et al. 2019).

Since 2013, the NRRTC has been engaged in (i) coordinating the national research programmes, (ii) building research capacity across the nation, and (iii) facilitating international research linkages, mainly with AfricaRice, the International Rice Research Institute (IRRI), and national rice research programmes in other countries. Currently, with the expansion of rice production in different parts of the country, a number of research centres are engaged in the national research programme.

The national rice research programme works closely with AfricaRice and IRRI. Ethiopia has been a full member of AfricaRice since 2016. The close collaboration with both AfricaRice and IRRI, mainly in terms of germplasm exchange and human and physical capacity building, has played a crucial role in the improved performance of Ethiopia's research system. In particular, this collaboration has supported the release of improved rice varieties for the three rice agro-ecologies of the country. 
Table 4.1 The gender dimension of rice farmers, Fogera plain

\begin{tabular}{|c|c|c|c|c|c|}
\hline \multirow[t]{2}{*}{ Variable } & \multirow[t]{2}{*}{ Indicators } & \multicolumn{3}{|c|}{ Gender of household head } & \multirow[t]{2}{*}{ F-value } \\
\hline & & Male $(n=645)$ & Female $(n=78)$ & Total $(n=723)$ & \\
\hline \multirow[t]{2}{*}{ Age of the household head (years) } & Mean & 43.91 & 45.81 & 44.12 & \multirow[t]{2}{*}{1.66} \\
\hline & Std & 12.46 & 10.29 & 12.25 & \\
\hline \multirow[t]{2}{*}{ Farming experience (years) } & Mean & 22.91 & 26.99 & 23.35 & \multirow[t]{2}{*}{$8.45^{\star \star \star}$} \\
\hline & Std & 11.85 & 10.41 & 11.76 & \\
\hline \multirow{2}{*}{$\begin{array}{l}\text { Experience of the household head } \\
\text { in growing rice (years) }\end{array}$} & Mean & 12.27 & 12.50 & 12.29 & \multirow[t]{2}{*}{0.09} \\
\hline & Std & 6.44 & 6.31 & 6.42 & \\
\hline \multirow[t]{2}{*}{ Household size } & Mean & 5.71 & 3.92 & 5.52 & \multirow[t]{2}{*}{$57.23^{\star \star \star}$} \\
\hline & Std & 1.99 & 1.81 & 2.04 & \\
\hline \multirow[t]{2}{*}{ Land size allocated for rice (ha) } & Mean & 0.75 & 0.52 & 0.72 & \multirow[t]{2}{*}{$23.63^{\star \star \star}$} \\
\hline & Std & 0.40 & 0.28 & 0.40 & \\
\hline \multirow[t]{2}{*}{ Number of plots cultivated for rice } & Mean & 2.71 & 1.86 & 2.62 & \multirow[t]{2}{*}{$28.73^{\star \star \star}$} \\
\hline & Std & 1.37 & 0.91 & 1.36 & \\
\hline \multirow[t]{2}{*}{ Rice productivity (qt/ha) } & Mean & 39.24 & 32.13 & 38.48 & \multirow[t]{2}{*}{$14.97^{\star \star \star}$} \\
\hline & Std & 15.20 & 13.64 & 15.19 & \\
\hline
\end{tabular}

Note: ${ }^{* \star \star}$ indicates significance at $1 \%$ and ${ }^{*}$ at $10 \%$

Source: APRA rice farmers' survey (2018)

In general, the research system has released 20 improved varieties for upland agro-ecologies, ten for lowland agro-ecologies, and seven for irrigated agro-ecologies, in addition to agronomic and related recommendations (MoA 2018).

There are also few pre-harvest, harvest, and postharvest technologies generated locally or imported through commercial routes. Adoption rates of such technologies are very low and rice farmers are fully dependent on traditional tools, using either human power or animals for the different operations, from land preparation to threshing (Getnet, Alebachew and Ageze 2019). This implies the need to strengthen the research coverage into pre-harvest, harvest, and post-harvest technologies with a clear mechanism of transfer for improved adoption.

\subsection{Technology multiplication}

The rice related technology multiplication is predominantly linked to seed multiplication of improved rice varieties. The main actors engaged in certified seed production are public seed enterprises, namely Ethiopian Seed Enterprise and regional seed enterprises (Amhara, Oromia, and South Seed Enterprises); the private seed company, Fikerte Newayeselasie Integrated Agri.Dev. PLC; and seed producers' cooperatives, namely Muez SPC in Tigray, Tikdem SPC in Amhara, and Hunde Misooma SPC in Oromia (Ayana and Alemu 2019).

Overall, both public and private seed companies are not interested in engaging in the production and marketing of certified seed for the available rice varieties due to the low level of demand for rice seed. This low level of demand is linked with the lack of proper promotion of the benefits of using quality seed for improved varieties. This has resulted in the low level of certified seed produced and marketed annually. The total estimated volume of certified seed produced in 2018 was only 10 t, compared to the 2,470 t required, based on the recommended seed rate of $0.14 \mathrm{t} / \mathrm{ha}$ and seed replacement rate of three years (Ayana and Alemu 2019). This trend indicates the limited engagement of seed actors in rice seed multiplication and the dominance of rice producers' use of their own seed, despite the release of 37 improved varieties for use. Similar to the seed systems for other crops, the poor performance of the rice seed system is linked to the policy, governance, and capacity challenges facing the national seed system. Specifically, this is associated with the absence of a clear organisational structure that guides and coordinates the seed sector, the lack of required human and physical capacity, and the lack of regulations and directives required to ensure the functionality of the sector (MoA 2019).

\subsection{Rice producers}

In Ethiopia, there are two types of rice producer. The first type are smallholder rice producers, who play a dominant role in the rice value chain, and the second type are the few commercial rice farms. The Central Statistical Agency's (CSA) 2019 data shows that there are 63,000 smallholder rice farmers, with an average 0.34ha of land allocated for rice per farmer (CSA 2019).

A survey conducted in the Fogera plain in 2018 indicated that about 11 per cent of smallholder rice farming households are female-headed and the 
remaining 89 per cent are male-headed households. About 82 per cent of the female-headed households are either divorced or widowed and the remaining 18 per cent are single.

The characteristics of rice farmers in Fogera plain indicates that female-headed rice farming households are, on average, less endowed with household labour given the smaller family size, estimated at about 4 persons compared to about 6 persons for male-headed rice farming households. Similarly, the land allocated for rice production is, on average, smaller compared to male-headed households. On average, female-headed households are allocated about 0.5ha of land and male-headed households are allocated about 0.75ha. The average rice productivity levels achieved by femaleheaded households is also smaller on average than male-headed households (Table 4.1).

In general, smallholder rice farmers are found at the seven major rice producing areas, which are often called the rice hubs. These are Fogera in Amhara, Pawi in Benishangul Gumuz, Abobo in Gambella, Chewaka in Oromia, Gura Fereda in the Southern Nations, Nationalities, and Peoples' Region (SNNPR), May Tsebri in Tigray, and Gode in Somali Region (Figure 4.2). The geographical diversity clearly indicates the potential for rice production in the country. It is estimated that 5.6 million ha of land is highly suitable for rice production (MoARD 2010).

In recognition of the country's potential, the availability of land for commercial farming, and the quest for import substitution to reduce the burden on Ethiopia's meagre foreign currency reserve, rice was considered as a priority commodity by the MoA in 2019, alongside cotton and oil crops. The government set different incentives for commercial investment in these crops. The main target of commercial rice farming was to curb the increasing rice imports and potentially export rice. Accordingly, commercial rice investments were licensed. This includes the official lease of 100,000ha to an Indian company, Karuturi Global, in Gambella, 100,000ha of land leased to Ethiopian company, Saudi Star PLC, in Gambella, and 2,000ha of land leased to Sino Farm PLC in Amhara, since 2009. Excepting Saudi Star PLC, which has managed to farm about 5,000ha of land in 2019, the other two companies did not manage to become operational. This implies the important role of smallholder rice farmers in domestic rice production.

\subsection{Collectors and farmer traders}

Collectors and farmer traders link smallholder rice producers with processors through the aggregation of paddy rice. Some of these actors operate on their own (farmer traders) and others operate on behalf of rice processors (collectors). They mainly operate in areas (kebeles) that are far from the towns and cities, where rice processors operate. The data from Fogera plain indicates that there are five to ten collectors/farmer traders per kebele. They operate on market days, where they buy using a balance. On average, they manage 1-2t of paddy per market day. The purchased paddy is then transported using donkey carts to nearby main

Table 4.2 Major challenges for rice processors by gender

\begin{tabular}{|c|c|c|c|c|c|}
\hline \multirow[t]{2}{*}{ Category } & \multirow{2}{*}{\multicolumn{2}{|c|}{ Challenges }} & \multicolumn{3}{|c|}{ Percentage } \\
\hline & & & $\begin{array}{l}\text { Male } \\
(n=112)\end{array}$ & $\begin{array}{l}\text { Female } \\
(n=11)\end{array}$ & $\begin{array}{l}\text { Total } \\
(n=123)\end{array}$ \\
\hline \multirow{3}{*}{$\begin{array}{l}\text { 1) Paddy } \\
\text { supply }\end{array}$} & a) & Supply of poor quality paddy rice & 91 & 100 & 92 \\
\hline & b) & Inadequate supply of paddy rice & 83 & 100 & 85 \\
\hline & c) & Challenges related with aggregation from small producers & 52 & 36 & 50 \\
\hline \multirow{2}{*}{$\begin{array}{l}\text { 2) Processing } \\
\text { technology }\end{array}$} & a) & Poor quality, old model or inefficient machines & 55 & 18 & 51 \\
\hline & b) & $\begin{array}{l}\text { Unavailability of quality and modern machines in the local } \\
\text { market }\end{array}$ & 65 & 36 & 63 \\
\hline \multirow{5}{*}{$\begin{array}{l}\text { 3) Required } \\
\text { resources }\end{array}$} & a) & Lack of land to expand processing business & 58 & 64 & 59 \\
\hline & b) & Lack of capital to expand processing business & 75 & 55 & 73 \\
\hline & c) & Lack of land to establish other businesses & 52 & 73 & 54 \\
\hline & d) & Lack of skilled labour for processing & 53 & 36 & 51 \\
\hline & e) & Frequent Interruption of electric power & 90 & 100 & 91 \\
\hline \multirow{4}{*}{$\begin{array}{l}\text { 4) Rice } \\
\text { markets }\end{array}$} & & Inadequate demand for rice & 59 & 82 & 61 \\
\hline & b) & Lack of price incentive for quality rice products & 55 & 91 & 59 \\
\hline & & Lack of market information & 45 & 27 & 43 \\
\hline & & Huge competition from imported rice & 71 & 73 & 71 \\
\hline
\end{tabular}

Source: APRA rice processors' survey (2018) 
Table 4.3 Role of rice processors in job creation by gender

\begin{tabular}{|c|c|c|c|c|c|}
\hline \multirow[t]{2}{*}{ Type of labour } & \multirow[t]{2}{*}{ Gender } & \multirow[t]{2}{*}{ Indicator } & \multicolumn{3}{|c|}{ Gender of rice processor } \\
\hline & & & Male ( $n=112)$ & Female (n=11) & Total (n=123) \\
\hline \multirow[t]{9}{*}{ Permanent } & \multirow[t]{3}{*}{ Male } & Mean & 4.65 & 3.45 & 4.54 \\
\hline & & Std & 3.22 & 1.37 & 3.11 \\
\hline & & $\mathrm{N}$ (\% of processors) & $103(92)$ & $11(100)$ & $114(93)$ \\
\hline & \multirow[t]{3}{*}{ Female } & Mean & 2.15 & 1.67 & 2.06 \\
\hline & & Std & 1.82 & 0.58 & 1.65 \\
\hline & & $\mathrm{N}$ (\% of processors) & $13(12)$ & $3(27)$ & $16(13)$ \\
\hline & \multirow[t]{3}{*}{ Total } & Mean & 4.92 & 3.91 & 4.82 \\
\hline & & Std & 3.51 & 1.87 & 3.40 \\
\hline & & $\mathrm{N}$ (\% of processors) & $103(84)$ & $11(100)$ & $114(93)$ \\
\hline \multirow[t]{9}{*}{ Casual } & \multirow[t]{3}{*}{ Male } & Mean & 8.45 & 5.13 & 8.13 \\
\hline & & Std & 9.68 & 4.64 & 9.35 \\
\hline & & $\mathrm{N}$ (\% of processors) & $76(68)$ & $8(73 \%)$ & $84(68)$ \\
\hline & \multirow[t]{3}{*}{ Female } & Mean & 2.75 & 1.00 & 2.40 \\
\hline & & Std & 3.81 & - & 3.44 \\
\hline & & $\mathrm{N}$ (\% of processors) & $8(7)$ & $2(18)$ & $10(8)$ \\
\hline & \multirow[t]{3}{*}{ Total } & Mean & 8.74 & 5.38 & 8.42 \\
\hline & & Std & 9.75 & 4.53 & 9.42 \\
\hline & & $\mathrm{N}$ (\% of processors) & $76(68)$ & $8(73)$ & $84(68)$ \\
\hline
\end{tabular}

Source: APRA rice processors' survey (2018)

roads, where there is formal transport to the nearby town or city to reach rice processors.

\subsection{Rice processors}

Rice processors in the Ethiopian rice value chain play a central role as paddy purchasers, service providers, and/or wholesalers of milled rice. In general, the emergence of a rice processing industry is not only a business opportunity for the processing facility owners, but has also helped to incentivise: (i) the expansion of rice production and rice markets; (ii) the creation of job opportunities (on average a processor creates ten job opportunities, both casual and permanent); and (iii) potential investment in other business areas like hospitality and tourism, fuel stations, and other processing industries.

The capacity of rice processors is small scale, ranging from 1-2t/day, using old model rice processing machines mainly imported from China ( $\mathrm{N}-90, \mathrm{~N}-70$, $\mathrm{Nx}-110, \mathrm{Sb}-30$, and Sb-50 types). A 2018 rice processors' survey indicated that there were 123 rice processors in Fogera plain, of which, 11 processors (10 per cent) were female owned. The importance of the key challenges facing processors differed between female and male operators, this was reflected in terms of the proportion of responses that identified each challenge in the survey (Table 4.2). The key challenges reported mainly by female operators were the poor quality and inadequacy of paddy supply, the instability of electricity supply, and the lack of price incentives for quality rice products. Challenges related to the lack of modern processing machines and associated skilled manpower were also reported to be among the most important.

In terms of creating job opportunities, the 2018 rice processors' survey indicates that all female rice processors hire permanent labour, estimated at about four employees per processor on average. About 84 per cent of the male processors indicated that they hire on average about five employees. About 73 per cent of the female processors indicated that they hire on average about five casual labourers on a daily basis and about 68 per cent of male processors hire on average about nine casual labourers on a daily basis. Both male and female processors hire more male labour compared to female labour (Table 4.3).

In general, rice processors provide milling services for free, with an agreement whereby they buy the milled rice or the paddy rice and keep the by-product (husk and bran with a certain amount of broken rice). Rice processors normally negotiate a unit price for the paddy or milled rice depending on different sourcing strategies, which include: (i) direct purchase from rice producers (dominant strategy); (ii) purchase through collectors on behalf of a processor or a broker (delala); and (iii) purchase from a farmer trader. The direct purchase arrangement often disincentivises rice processors to ensure quality processing as it allows the transfer of possible income loss due to the risk of paddy quality from the processor to the producer. Additionally, it gives 
processors the opportunity to maximise the benefits they receive from the by-products, which are further processed into rice flour and then sold by the processor.

\subsection{Wholesalers/importers}

In general, there are three types of wholesalers in the Ethiopian rice value chain context. The first are, as indicated above, rice processors, who act as wholesalers for domestic milled rice. The second are those traders that act as wholesalers for domestic rice found in urban areas, where there are no rice processors. These traders have a direct link with rice processors in a different part of the country. They are found in all major towns and cities all over the country. The third type of wholesalers are rice importers engaged in the import of rice from abroad and the majority of them are found in Addis Ababa. All types of wholesalers sell milled rice to retailers and different types of consumers (households, restaurants, hotels, and other institutional buyers). They are not specialised in exclusively selling rice, but are also engaged in the wholesale of other grains.

\subsection{Retaillers}

Actors engaged in rice retailing are diverse and include flour millers, supermarkets, and grain retailers. Flour millers are very important in rice retailing, as rice is mixed with teff for making ingera, the most popular food in the country. The mixing of rice with teff is the major reason for the considerable volume of broken rice imports. It is also a disincentive for quality rice processing. In major towns, the ratio of mixed flour used for ingera is reported at 10-40 per cent rice flour and the rest teff. Supermarkets are major retailers of mainly imported rice of different quality, including basmati types. There is an emerging trend of packing domestic rice and retailing it through supermarkets.

\subsection{Support service providers}

Ethiopia has a federal public setup and the public support services are aligned accordingly. A diverse range of services are provided at federal, regional, zonal, woreda (district), and kebele level. Rice related support services include (i) the public agricultural extension services, as per the national rice extension package (a manual that advised farmers on recommended technologies/ varieties, good agronomic practices, and improved post-harvest management); and (ii) the facilitated supply of required inputs mainly seed, fertiliser, and other chemicals. These services are provided by respective agricultural offices in the main rice growing hubs in the country (Figure 3.1 and 4.1).

\subsection{Rice consumers}

In Ethiopia, rice is consumed in different forms. The most common way rice is consumed is as ingera, which is made of a flour mixture of rice and teff, genfo, and kita. It is also commonly consumed as boiled rice and used to make traditional liquors (Tela and Areki). The most traditional food item in Ethiopia, commonly found on the table for breakfast, lunch, and dinner, is injera. The trend for making ingera from a mix of teff and rice is increasing, mainly due to the preferred colour (whitish ingera is the most preferred) and the unit price advantage. On average, the unit price of teff is higher than the unit price of rice by about 30 per cent. Depending on the ratio of teff to rice in the mixture, which is reported to range from 10-40 per cent rice and 90-60 per cent teff, the cost of making ingera is significantly reduced by using rice flour. This trend has also resulted in the limited incentive for domestic rice processors for processing quality rice and the importation of considerable quantities of broken rice from abroad.

Though households also consume boiled rice, much of this is served in hotels, restaurants, and institutions, like universities, colleges, and army camps. Discussions with key informants and observations carried out in retail shops indicate that 90 per cent of the boiled unbroken rice consumed is imported and it is mainly different types of basmati rice.

\subsection{Price across the rice value chain}

The price ranges across the different value chain actors are presented in Table 4.4. The farm gate price for paddy rice ranged from 6,000 Birr/t to 13,500 Birr/t. This variability is a reflection of the seasons over the year and the specific location - the distance from the processors and major market centres.

Table 4.4 Prices of domestic rice across the value chain, 2019

\begin{tabular}{|l|l|l|}
\hline \multirow{2}{*}{ Actor } & Unit price (Birr/t) \\
\cline { 2 - 3 } & Min & Max \\
\hline Rice producers (paddy) & 6,000 & 13,500 \\
\hline Collectors/farmer trader (paddy) & 6,500 & 18,000 \\
\hline Processors (white rice) & 7,000 & 21,000 \\
\hline Wholesalers (white rice) & 13,500 & 22,000 \\
\hline Retailers (white rice) & 14,000 & 25,000 \\
\hline
\end{tabular}

Source: Authors' own survey (2019) in Fogera plain and major cities (Bahir Dar and Addis Ababa) 
The price mark-ups across the actors and the wide range in price over a year indicate the considerable price variability in the country by location and season. Despite the relative substitutability of teff with rice, the price range of rice is by far lower than teff, making the demand for rice high. The teff price range in 2019 was from 20,000 Birr/t to 40,000 Birr/t.

\subsection{Rice value chain governance}

In general, value chain governance covers issues related to (i) power distribution dynamics and relationships among value chain actors, (ii) the way transactions are organised, and (iii) the creation of an enabling environment for improved value chain performance (Watabaji, Molnar and Gellynck 2016; Crisan, Parpucea and llies 2011). It is important, particularly for the generation, transfer, and diffusion of knowledge, which leads to innovations that enable value chain actors to improve their performance and sustain a competitive advantage. Similarly, knowledge of the governance structure of a value chain can provide governments, donors, and development practitioners with information about how best to provide the support services needed to upgrade actors' position in the value chain (Gereffi, Humphrey and Sturgeon 2005).

The 2010 National Rice Research and Development Strategy indicates how the rice value chain is governed from the public service perspective. Accordingly, the key actors along with their roles and responsibilities are as follows:

- The National Rice Research and Development Steering Committee: chaired by the state minister of the Ministry of Agriculture (MoA). Members of the Committee are relevant directors of the MoA and regional bureaus of agriculture, Director Generals of EIAR and regional agricultural research institutes, development partners, and representatives of the private sector. The main role of the committee is to oversee the implementation of the strategy and regularly follow up on progress through its bi-annual meetings and field visits.

- The National Rice Secretariat: based at the MoA, the Secretariat operates with the financial and technical support of the government of Japan through JICA. As the name indicates, it is responsible for the day-to-day follow up and technical backstopping of the implementation of the strategy, along with decisions made during the Steering Committee meetings. It also supports the activities of the National Rice Technical Committee.
- The National Rice Technical Committee: is responsible for undertaking technical activities related to decisions made by the Steering Committee. It is composed of experts from the MoA, Agricultural Transformation Agency, and the NRRTC.

- Regional focal persons: each regional bureau of agriculture has an assigned focal person, who is directly linked to the National Rice Secretariat and Technical Committee. The focal person assists the National Rice Technical Committee.

In 2019, there was an initiative to establish a National Rice Stakeholders' Platform to ensure adequate participation of the key value chain actors, especially the private sector. Accordingly, the National Rice Secretariat facilitated the organisation of the first National Rice Stakeholders' Platform in 2019 with the long-term objective to transform the platform into a legally recognised association, which will operate independently to safeguard the interests of rice value chain actors. The actors that participated in the platform were representatives of rice producers, processors, supermarket owners, donor supported projects engaged in rice promotion, and representatives from the MoA and regional bureaus of agriculture. As the importance of rice is increasing, along with the number and diversity of rice value chain actors, it is expected that the platform will grow into an association, as has been the case for crops like coffee and pulses, and oil crops. The infant stage of rice value chain governance and the limited participation of key actors (the private sector) has resulted in issues related to the informal operation of transactions and product standardisation, based on informal market information exchanges.

The discussions with key informants indicate that the relationships among actors engaged in buying and selling rice, the provision of required services, and regulatory institutions that operate in the rice value chain are very weak. The key challenges associated with these relationships are as follows:

- Much of the effort to ensure strong linkages among actors in the rice value chain is driven by public programmes. It is only recently, in 2019, that an initiative to establish a rice stakeholders' platform that involves private actors was started.

- $\quad$ The operations of the National Rice Steering Committee are heavily dependent on the push from the National Rice Secretariat, which has resulted in the ad hoc engagement of the Steering Committee in promoting the rice sector. 
- The National Rice Secretariat is a donor supported office (funded by JICA) and its activities are determined by the availability of resources and interests of the assigned foreign experts. This limits the sustainability of activities and its engagement with the Steering and Technical Committees.

- At the regional level, the implementation of planned activities depends on the interests and motivation of assigned focal persons. This has resulted in a diversity of performance in promoting rice sector development across different regions.

- The engagement of non-government actors, mainly private sector actors, to ensure effective governance and linkage among value chain actors is very limited.

These challenges have resulted in the continuation of traditional operations and relationships along the rice value chain. As a result, the setting, monitoring, and enforcement of standard behaviour and practices in the value chain, which can ensure enhanced competition between actors and rice products, is limited. 
The global attention given to rice, especially in Africa, is linked with the considerable increase in demand for rice in Africa and the continuous decline in the level of rice self-sufficiency. As a result of this trend, a rice specific continental initiative, CARD, was launched in 2008. CARD is a joint initiative involving the Comprehensive African Agriculture Development Programme, JICA, the Alliance for a Green Revolution in Africa, and the New Partnership for Africa's Development Planning and Coordination Agency.

The CARD initiative has played a crucial role in rice sector development in different African countries, including in Ethiopia. It is through the facilitation of the CARD initiative that Ethiopia developed its first National Rice Research and Development Strategy in 2010 (2010-2019), which has been guiding the overall rice sector development (Ismail 2019). The overall target of the strategy, as in other African countries, was the doubling of rice production over ten years (2009-2019). Ethiopia has more than doubled its total annual rice production from 71,400t in 2009 to 172,000t in 2019 (Ismail 2019). The new CARD initiative, which has the same objective to facilitate the doubling of rice production in Africa (2020-2030) has already started and Ethiopia is expected to benefit it. Accordingly, a new rice development strategy (2020-2030), which was developed with the facilitation of the CARD initiative, was approved by the Ethiopian MoA in February 2020. The new strategy aims to transform the rice sector to considerably reduce Ethiopia's dependence on rice imports. Specifically, it aims to increase the area of land allocated for rice production under smallholder farming from about 63,000ha to about 330,000ha and the area of land allocated the rice production under private commercial farming from about 2,000ha to about 60,000ha over ten years (MoA 2020).

AfricaRice plays a very crucial role in facilitating the release of improved rice varieties for the different rice agro-ecologies in Ethiopia. With the exception of a few varieties, all released varieties in Ethiopia are from the germplasm sourced from AfricaRice. AfricaRice is a panAfrican research for development intergovernmental association of 27 African member states and Ethiopia has been a member since 2016 (Roy-Macauley 2019).
Similarly, $|\mathrm{RR}|$ works closely with the national rice research programme, targeting germplasm exchange and human capacity development.

The support through technical cooperation and grants by the Japanese government has played a crucial role at different levels of the rice value chain and its performance. JICA's technical and financial support to the National Rice Secretariat facilitated the design of the National Rice Research and Development Strategy in 2010 and its revision in 2019. JICA also assisted the MoA in the monitoring and evaluation of the implementation of the strategy. The construction of the NRRTC was made possible through a Japanese grant, which is the third Japanese grant to support the establishment of rice research and training centres in the East Africa region, with one developed in Tanzania and a second in Uganda. The five-year JICA project to enhance the functioning of the NRRTC under the EIAR is helping to increase Ethiopia's rice research capacity in terms of human resource development, experience sharing, and providing lab and other important equipment. The Japanese government's investment is in support of the CARD initiative's aim to ensure the doubling of rice production in Africa by 2030.

Specific projects targeted at rice value chain development have also contributed to the sector's development. These include the Ethiopians Driving Growth through Entrepreneurship and Trade (EDGET: 2011-2016) and Ethiopians Motivating Enterprises to Rise in Trade and Agri-business (EMERTA: 20172022) projects implemented by MEDA. MEDA is a Canadian based international non-governmental organisation with more than 60 years of experience in international development. The projects targeted the development of the rice value chain in Fogera plain in Amhara region and the Gura Ferda area in SNNPR. The MEDA projects' interventions included the promotion of (i) production by ensuring improved input supplies, awareness of improved techniques, irrigation, including efficient micro-irrigation technologies, and rural credit, (ii) post-harvest handling by introducing innovations in rice storage, grading, and market segmentation, as well as improved technologies for value added activities, and iii) market linkages by capacitating smallholder rice 
Table 5.1 Development partners and their role in rice sector development in Ethiopia

\begin{tabular}{|c|c|c|}
\hline Organisation & Area of support & Period \\
\hline CARD & $\begin{array}{l}\text { Facilitates the development of strategic documents, experience } \\
\text { sharing, and capacity building. For example, CARD: } \\
\text { - Facilitated the development and revision of the National Rice } \\
\text { Research and Development Strategy and National Rice Seed } \\
\text { Sector Development Strategy. } \\
\text { - Facilitated a number of exchange visits to Uganda and Tanzania. }\end{array}$ & $\begin{array}{l}\text { Ethiopia has been a } \\
\text { member since } 2008\end{array}$ \\
\hline AfricaRice & $\begin{array}{l}\text { Supports the national rice research programme through germplasm } \\
\text { exchange, joint research, and human capacity building. }\end{array}$ & $\begin{array}{l}\text { Ethiopia has been a } \\
\text { member since } 2016\end{array}$ \\
\hline$|\mathrm{RR}|$ & $\begin{array}{l}\text { Supports national rice research through germplasm exchange and } \\
\text { capacity building. }\end{array}$ & Since early 1990s \\
\hline $\begin{array}{l}\text { JICA } \\
\text { government of } \\
\text { Japan }\end{array}$ & $\begin{array}{l}\text { - Invested in the construction of the facilities of the NRRTC. } \\
\text { - Invests, through the EthioRice project, in the functioning of the } \\
\text { NRRTC. } \\
\text { - } \text { Provides short- and long-term training for rice researchers. } \\
\text { - } \text { Assigned senior advisor to the MoA to technically backstop the } \\
\text { - } \quad \text { Finanional Rice Secretariat. }\end{array}$ & Since 2010 \\
\hline $\begin{array}{l}\text { Mennonite } \\
\text { Economic } \\
\text { Development } \\
\text { Associates } \\
\text { (MEDA) }\end{array}$ & Facilitates rice value chain development in the country. & $\begin{array}{l}\text { First phase } \\
\text { (2011-2016) } \\
\text { Second phase } \\
\text { (2017-2022) }\end{array}$ \\
\hline $\begin{array}{l}\text { AgroBIG } \\
\text { (Agro-Business } \\
\text { Induced Growth) } \\
\text { in Amhara } \\
\text { regional state }\end{array}$ & $\begin{array}{l}\text { Supports agribusiness development for selected commodities, } \\
\text { including rice, targeting the Lake Tana basin. }\end{array}$ & $\begin{array}{l}\text { First phase } \\
\text { (2013-2016) } \\
\text { Second phase } \\
\text { (2017-2021) }\end{array}$ \\
\hline
\end{tabular}

Source: Authors' own summary

farmers to deal more effectively with traders and by developing marketing strategies for new markets (Yimer 2019; Hostetter 2011).

The other project with rice specific interventions is AgroBIG in Amhara regional state, which is a bilateral agribusiness development programme financed by the Ethiopian and Finnish governments. During its first phase of implementation (2013-2016), the project supported the capacity building of value chain actors and facilitated access to finance and financial services for farmers, traders, processors, other entrepreneurs, and cooperatives engaged in production, agroprocessing, and service provision in rice, along with other commodities in the target districts (Fogera and Mecha districts) of Fogera plain. The second phase (2017-2021) continues building on the achievements in the first phase with extended area coverage, from two to eight districts around Lake Tana, covering Gumara, Koga-Gilgel Abay, and Rib river catchments (AgroBIG II 2018)

The review of development partners' role in enhancing the rice value chain in the country (Figure 5.1) indicates their importance in terms of (i) introducing technologies and innovations from abroad, (ii) capacity building, both in terms of human and physical infrastructure, (iii) enhancing stakeholders' linkages, and (iv) facilitating the development of public policy and strategic documents for rice research and development. As a global commodity, rice is the most researched crop, with the existence of advanced technologies to enhance its production, processing, and marketing in different countries. Ethiopia can introduce these technologies and adapt the rice value chain to enable quicker sector development in an effort to ensure self-sufficiency. 


\section{PIIEE, LAND, AND AGGESS TO Irapleation}

The commercialisation of rice in the Fogera plain since the start of its production in the late 1970s has contributed to the emergence of formal and informal land markets. In Ethiopia, the issue of land has been the centre of all political changes. During the imperial era before 1975, land was concentrated in the hands of absentee landlords and many ha of land were severely underutilised. During the Derg regime, ownership of all rural land was transferred to the state for the distribution of use rights to cultivators through local peasant associations. Following the fall of Derg in 1991, rural land was administratively allocated to farmers, giving them use rights. However, based on the new Rural Land Administration Proclamation, No. 89/1997, regional governments were given the responsibility of land administration, defined as the assignment of holding rights and the distribution of holdings. The holding rights of smallholder farmers were confined to (i) use only for agricultural purposes, (ii) lease for agricultural purposes, and (iii) bequeath to a family member (Deininger et al. 2003).

Linked to the challenges related to land administration since 1997, especially in terms of limited tenure security, the government designed a programme of land ownership certification. This certification programme is reported to have reduced land border conflict, helped to empower women, and improved governance at the local level. It is also expected to have an impact in terms of investment and productivity impacts (Deininger, Zevenbergen and Ali 2006). As per the provision of the federal Rural Land Administration Proclamation, No. 89/1997, a regional proclamation on rural land administration was enacted in 2017 (Proclamation No. 252/2017) in Amhara region. To ensure the implementation of the Proclamation, Rural and Administration Directive No. 1/2018, Land Use Directive No. 2/2018, Kebele Development Centre Directive No. 4/2018 were enacted and implemented. Within these prevailing policy frameworks in the region, the land markets in Fogera plain follow two approaches, namely land sharing and leasing, which are either formal or informal legal arrangements. In addition, due to an increase in the number of landless youth formerly common grazing lands have been allocated to farmers.

The focus group discussions (FGDs) conducted by the authors in the Fogera plain indicated that there are a number of challenges in the market led land transfer systems. The first challenge is related to the enforcement of legal agreements, especially for poor and female-headed households, as the legal process is reported to be very bureaucratic and costly. The second challenge is related to the limited efficiency of the land transfer market system. It is very difficult for a household to be aware of available land that can be

Figure 6.1 Trends in the number of youth and size of land allocated in Fogera district

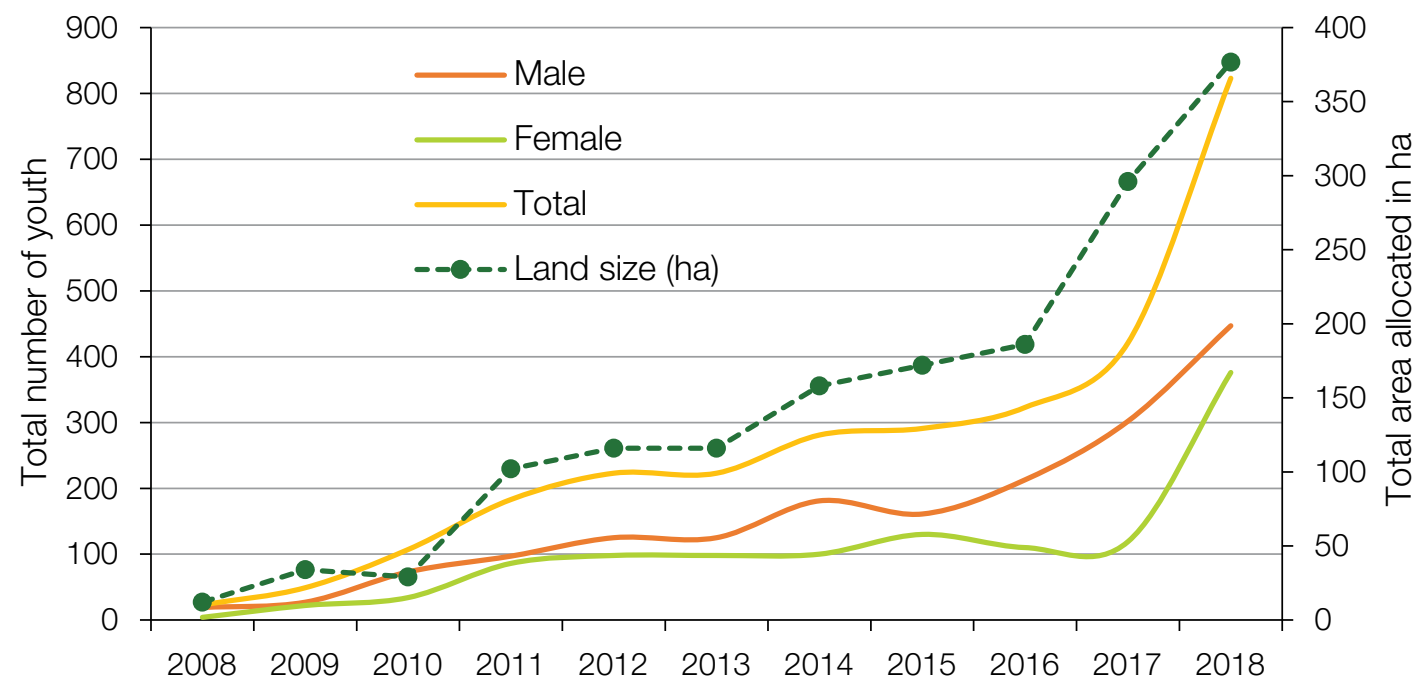

Source: Fogera woreda land administration office 
Table 6.1 Access to irrigation by gender ( $\%$ of households)

\begin{tabular}{|l|l|l|l|l|}
\hline Access to irrigation & Male $(n=645)$ & Female $(n=78)$ & Total $(n=723)$ & Chi-square \\
\hline No access & 53.5 & 65.4 & 54.8 & $3.98^{\star \star}$ \\
\hline With access & 46.5 & 34.6 & 45.2 & \\
\hline
\end{tabular}

Note: ${ }^{*}$ indicates statistical significance at $5 \%$

Source: APRA Ethiopia rice farmers' survey (2018)

rented and shared as there is no adequate information system in the area.

The other land transfer mechanism is through the administrative land allocation to rural youth, which mainly involves the distribution of communal lands. With increased landlessness in different parts of the country, there is a trend in allocating communal land to youth. Specifically, youth who are married and less than 35 years of age, with parents living in the area, are considered for land allocation by local authorities. The trend in the growing number of youth beneficiaries indicates that close to 1,600ha of land was distributed to about 2,950 youth over the last ten years in Fogera woreda alone (Figure 6.1). The different land transfer mechanisms are reported to have created opportunities for the transfer of land from those who cannot well manage the land due to their absence in the locality or due to a shortage of labour, especially among female-headed households, to those who are landless, especially youth households.

The 2018 smallholder rice survey indicated that about 45 per cent of farmers had access to irrigation with a statistically significant difference between male and female-headed households. About 47 per cent of male and 35 per cent of female-headed households had access to irrigation. Given the huge potential of the Fogera plain for easily accessed irrigation, the current extent of access implies the need for further investment to ensure improved access to irrigation. 


\section{RICE AND THE RURAL LABOUR MARKET}

The expansion of rice production and the associated development of the rice value chain has created diverse opportunities for different social groups. The major contribution of the expansion of rice production has been the development of rural labour, which has created job opportunities for rural youth as labourers. For instance, Fogera plain was known for its high outflow of rural youth as seasonal migrants and sometimes as migrants to other parts of the country. However, with increased rice production and processing in the Fogera plain, a labour market has developed creating opportunities for seasonal migrant labour to be employed locally. The 2018 rural labourers' survey data indicates that from the total sampled labourers (265), 66 per cent were landless and fully dependent on the labour market, 15 per cent were women, and almost all labourers came from Fogera plain.

The availability of labourers allows farmers to undertake the most important agronomic practices in a timely fashion, mainly planting, weeding, harvesting, and threshing. As indicated in part 4, the data from Fogera plain suggests that about 52 per cent of smallholder rice farmers fulfil their labour demand using hired labour, and a rice processor on average hires six casual labourers. 


\section{POLICY MAKING WITHIN THE RICE VALUE CHAIN: DISCOURSES, DEBATES, AND POLICIES/DIRECTIVES}

The main discourses on rice value chain development in Ethiopia revolve around the views of policy makers and practitioners. These views may or may not emanate from existing policies and directives related to smallholder versus commercial farms, domestic versus foreign investment, and the associated roles of private, public, and development partners in promoting the rice value chain. Accordingly, the main prevailing discourses around the commercialisation of the rice value chain are related to i) the relationship between domestic and imported rice and ensuring self-sufficiency in rice, (ii) the importance of smallholder versus commercial rice farming, (iii) the need to modernise rice processing to incentivise quality rice processing and the prevailing disincentives facing rice processors, (iv) the implication of rice expansion for the production of other crop, (v) ensuring social inclusion and youth employment, and (vi) rice statistics.

\subsection{Ensuring the competitiveness of domestic rice with imported rice: ensuring self-sufficiency}

The dramatic increase in rice imports from year to year has forced policy makers to explore different mechanisms to curb the trend and ensure selfsufficiency by 2030 (MoA 2020). One approach is to enhance the competitiveness of domestic rice in terms of quantity, quality, and prices. In general, the competitiveness of domestic rice depends on the extent that the challenges facing the rice sector, in terms of the nature of production, processing, and the marketing system, are addressed.

The key challenges at the production level, which contribute to limited competitiveness are associated with (i) the small scale nature of production and the diversity in farmers' rice production practices that affect the quality in terms of uniformity in grain size, maturity, and purity; (ii) the lack of awareness and shortage of pre-harvest and production management skills; (iii) the lack of post-harvest mechanisation and inadequate awareness of post-harvest management and utilisation; and (iv) the marketing relationship between rice producers and rice processors, which does not provide incentives for quality paddy production. At the processing level, the challenges include the limited price differentiation for different grades of milled rice and the huge demand for broken rice, linked to the use of rice flour for making ingera. This has the direct implication of disincentivising rice processors from processing qualitymilled rice. In addition, there is no clear policy direction related to the role of the public sector in (i) enhancing the competitiveness of the domestic rice sector, particularly through policy measures that disincentivise rice imports, and (ii) promoting the professionalisation and standardisation of domestic rice processing (Assaye and Alemu 2020).

In addition to the challenges linked to the competitiveness of domestic rice, there is also a divergence in rice market niches. The rice market niches and the policy planning and implementation strategies towards selfsufficiency in rice do not appear to be well aligned. In general, Ethiopia imports three types of quality rice, namely milled, brown (husked), and broken rice. A considerable proportion of imported rice is broken rice (about 20 per cent of total rice imports), which is often imported at a dumping price and creates a burden on the competitiveness of domestic rice. In terms of seed type, there are two major types: (i) long-grain rice seed, which is often called basmati rice and (ii) shortgrain rice seed. Domestically produced rice consists of entirely short-grain rice types. This implies that Ethiopia will remain dependent on imports for basmati rice (the Indian rice type), as there is no research, registered variety, or production of long-grain rice in the country. On the other hand, there are two types of short-grain rice grown in Ethiopia, namely Japonica rice, which is grown in the lowland agro-ecologies, and the NERICA types (hybrids of African and Asian rice types) grown in upland agro-ecological conditions.

The two types of short-grain rice grown in Ethiopia are not commonly consumed by urban dwellers due to the lack of grading and packaging. In this regard, there have been a number of project-based efforts to promote the grading and packaging of domestic rice and channel it to consumers through supermarkets in urban areas. However, none of the efforts have lasted long, mainly due to the instability of paddy supply in the required quantities and quality. A good example is Endoto Import-Export PLC, a company also engaged in the importation of rice from India and Pakistan. With 
the facilitation of MEDA to build linkages between producers and the company, Endoto Import-Export PLC started processing, grading, and packing domestic rice under the brand Addis-Rice. The marketing was also facilitated through a contractual arrangement with about 12 supermarkets found in Addis Ababa. The effort was sustained for two years and then stopped, mainly due to the shortage of paddy supply.

These challenges imply that the type of rice produced locally and the quality of processing and packaging will be crucial in determining whether domestic rice can fulfil the requirements of the different niche rice markets in the country. The rising demand for basmati rice will remain a challenge. This duality of markets for rice, associated with the difference in demand in terms quality and type of rice between urban and rural customers, has been a key challenge in Sub-Saharan Africa and resulted in the limited competitiveness of local rice (Woperies et al. 2013).

\subsection{Commercial versus smallholder rice production}

The role of commercial versus smallholder agricultural production has been one of the key political issues in policy and strategy design in the country. It was during the Plan for Accelerated and Sustained Development to End Poverty (2005-2010) that large scale commercial agriculture was encouraged. This strategy was based on the assumption that commercial agriculture would serve as a means of boosting production for domestic use and export, augmenting farmers' income, generating alternative employment opportunities for smallholders, and increasing government revenue (Alemu and Berhanu 2018). The subsequent national Growth and Transformation Plan I and II (GTP I: 20102015 and GTP II: 2015-2020) sustained the promotion of commercial farming with the same assumption, but only for selected commodities that contribute either to import substitution or export. The targets for investment in large-scale commercial farming were lowland areas, which are considered to have underutilised land. The main tools to incentivise commercial farming for priority sectors are i) the provision of land with competitive lease prices, ii) investment credit support, and iii) fiscal incentives in terms of tax holidays, duty free imports of capital goods, and duty exemption for raw materials used as inputs for export.

Among the overall provisions to promote commercial farming, rice has been one of the priority commodities for commercial investment. The main objectives for considering rice as a priority commercial investment are to ensure import substitution to counter increasing demands for rice imports and the burden this creates on Ethiopia's meagre foreign currency reserve, and to create livelihood opportunities for local communities. In this regard, a number of huge land concessions were made, including the lease of 100,000 ha each to Saudi Star PLC and India-based conglomerate known as Karuturi Global Limited in Gambella region. Due to the limited success of these investments, the size of leased land was considerably reduced. It is only Saudi Star PLC that has managed to cultivate any land, with about 6,000 ha of land under production. Karuturi Global Limited did not manage to sustain any operations and the investment license was revoked. These trends indicate the limited success of the promotion of commercial rice production, though there was huge expectation that it would contribute to Ethiopia's selfsufficiency in rice.

Linked to the experiences of public investment in wheat production in lowland areas, there is a public initiative to promote large-scale rice production at the vast irrigated lands owned by sugar estates in lowland areas. Irrigated wheat production, promoted since 2019, shows promising results and it is intended to ensure selfsufficiency in wheat by 2023 . Estimates indicate that the country spends from US\$500 million to US\$700 million on importing wheat annually. From the public policy perspective, the intention is still to demonstrate that both wheat and rice can be produced successfully in the lowlands and to then transfer production to private commercial actors to ensure sustainability. As commercial rice production increases, competition with smallholder rice production is expected to be high, which may affect the expected expansion of rice production at the national level. Thus, it will be important to design complementarity between smallholder rice production and the emerging commercial rice production in terms of technology transfer, service provision, and enhancing market linkages.

\subsection{The professionalisation and standardisation of domestic rice processing}

The role of rice processors in the rice value chain is very important in the Ethiopian context as they serve a dual purpose. Rice processors are not only responsible for processing, but also for wholesaling milled rice, given the unique marketing arrangement between rice producers and processors. In addition, due to buyers' limited product differentiations of milled rice and the disincentive for processing quality rice, rice processors do not target and invest in enhancing quality rice processing, which could compete with imported rice (Assaye and Alemu 2020). On the other hand, the national rice sector development strategy indicates the need to ensure rice import substitution, mainly to 
reduce the burden rice creates on the country's meagre foreign currency reserves (MoARD 2010).

Accordingly, there is a debate around the need for the professionalisation and standardisation of domestic rice processing in the country through policy provisions and capacity building (training). Since rice is an introduced commodity, the level of knowledge and skill available required to modernise the sector in the country is limited. However, globally, rice is the most researched crop with diverse technological options available. For this reason the Ethiopian government, with the support of the Japanese government, established the rice specific NRRTC at Fogera, as one of the research centres of the EIAR. Unlike other research centres, NRRTC is mandated to provide capacity building for all actors in the rice value chain through the provision of certified trainings. However, the capacity building activities, along with demonstrations of the technological options, have not yet been implemented, though policy makers are aware of their need.

\subsection{Rice expansion and the implication for other crops and livestock}

The design of the national rice sector development strategy has been challenged in relation to the implications of rice expansion for other important cereal crops. The non-competitive expansion in rice production targets (i) the use of waterlogged areas, including much of the lowland areas of Fogera plain, where other crops cannot grow, and (ii) the use of underutilised land, mainly in the lowland areas of the country with access to irrigation. This expansion is more relevant for the lowland and irrigated rice agro-ecologies. However, with the introduction of upland rice, rice is expanding considerably to replace other crops. Assessment of the dynamics of farming systems in rice producing areas indicate that there is a considerable shift in the land use patterns.

The data generated from Fogera plain indicates that in the lowland areas, coverage of the cultivated area by rice increased from about 5 per cent in the 1990s to about 50 per cent in 2017. Similarly, in the upland areas of Fogera plain, the coverage of cultivated land by rice has increased from nil during the 1990s to about 12 per cent of the total cultivated land in 2017 . Thus, it is clear that the expansion of rice production will have two dimensions, where it will allow proper utilisation of underutilised areas on the one hand, but it will also replace other crops on the other hand.

Fogera plain is known for the Fogera cattle breed. The FGDs with local experts and farmers indicated that rice expansion has resulted in the decline of livestock production, mainly in the lowland areas where much of the area was waterlogged and used for grazing. It was indicated that this has resulted in the decline in the availability of dairy products. There is also a serious concern about the genetic erosion of the Fogera cattle breed as cattle rearing is moving to the upland areas of the Fogera Plain, which is not suitable for Fogera cattle breed.

\subsection{The role of rice in ensuring social inclusion and youth employment}

The unique nature of rice, mainly in relation to the high labour intensity, the potential for professional and non-professional job creation, and the spill over effect in economic opportunities, through improved rural urban linkages, has put rice at the forefront of discussions related to youth employment and social inclusion, especially in empowering women. The experiences of Wereta town of the Fogera plain, show that rice production and its commercialisation have played a crucial role in enhancing job opportunities. These opportunities include temporary (casual) and permanent employment in rice production, processing, and marketing, as well as jobs in the different businesses established through the spill over effects of the rice sector (e.g. hospitality and tourism, banking, fuel stations, other processing industries, and smaller businesses), which have flourished in the town (Taddesse, Alemu and Assaye 2020).

The allocation of communal land to youth for rice production has considerably contributed to job creation for landless youth families. Between 2008 and 2018, 1,600 ha of communal land was distributed to about 2,950 landless youth families in Fogera woreda, allowing them to engage in rice production as their livelihood option.

The government's effort to promote rice mechanisation since 2010 is expected to promote youth employment. Emerging tractor, plant protection, and transport services are boosting youth employment. The local office of employment promotion in Wereta town is highly engaged in supporting youth to have better access to finance, human capacity building, and public services. The office's activities are intended to ensure the engagement of youth in the stated service provision businesses.

The spill over effects of rice commercialisation have also helped to expand small businesses managed by mainly women, like restaurants, coffee houses, and kiosks. The expansion of small businesses in Wereta town indicates a boom. Between 2010 and 2020, the 
total number of category ' $A$ ' businesses has increased from zero to 78 , the number of category ' $B$ ' businesses has increased from 62 to 148, and the number of category ' $C$ ' businesses has increased from 809 to 1,516 (Taddesse, Alemu and Assaye 2020). ${ }^{1}$ These trends clearly indicate how the spill over effect of rice commercialisation, linked with private investment, has flourished across the city, which has stimulated income for locals through the creation of further jobs.

\subsection{The debate on rice production statistics}

Usually, policy making and planning depend on the use of reliable data/statistics about the number of producers engaged and level of production and productivity. Though, Ethiopia is among the African countries with a relatively well-developed agricultural statistics system (Benin et al. 2020), rice statistics in Ethiopia have been a point of discussion since the development of the National Rice Research and Development Strategy in 2010. The national policy direction for any statistics is related to the statistics generated by the CSA. The CSA generates agricultural statistics annually based on an Agricultural Sample Survey (AgSS), which includes data collected from 20 agricultural households per enumeration area (EA) from a total of 1,473 EAs all over the country (CSA 2019). This assumes the uniform distribution of the production of all crops, including rice, across the country. However, rice production is found in seven niche areas, which may create statistical bias in the AgSS as the statistics on ricovid-co3pkce depend on whether an EA falls in any of the rice hubs. This has been a point of debate in the development of the 2010 National Rice Research and Development Strategy and its revision in 2019. Accordingly, the figures in the 2010 strategy and CSA are different, creating confusion about the importance of rice in terms of the extent of domestic rice production. The figures stated in the 2010 strategy indicate that 284,868 farmers were engaged in rice production, covering 155,886 ha of land in 2009 , while the CSA estimates that 80,500 smallholders we engaged in rice production, covering 35,088ha of land. The debate still continues, but the revised National Rice Research and Development Strategy used CSA data for projections in 2019. The challenge related to rice statistics is well recognised by experts at CSA and recommendations have been made to have a rice specific survey for better estimation. 
This section presents the results of a rapid assessment of the impacts of COVID-19 on the rice value chain in Ethiopia. The assessment covered a review of the COVID-19 related measures, discussions with rice value chain actors, including farmers, processors, traders, and experts working for the Amhara Regional Bureau of Agriculture and for the Fogera District Office of Agriculture, and personal observations in the area.

In general, the impact of the COVID-19 pandemic on the rice value chain emanates from (i) the restrictive public measures put in place, (ii) the type and extent of responses in the commercial behaviours of the different rice value chain actors, and (iii) overall global trends in response to the challenges faced.

\subsection{The importance of COVID-19 public measures}

The first confirmation of a COVID-19 case in Ethiopia was on 13 March 2020 and with the increase in cases, the government declared a state of emergency (SoE) on 10 April 2020. The SoE and its implementation directive determined the different measures and restrictions applied nationally. The key measures and restrictions that are relevant to the rice value chain were (i) mobility restrictions and the increased cost of transportation for both humans and goods, (ii) the establishment of command posts (taskforces) at different administration levels for the follow up and control of the movement of goods and pricing as per the directives, and (iii) reduced public services that have associations with rice production, processing, and marketing.

- Mobility restrictions and the increased cost of transportation: the mobility restrictions were for a short period of time (two weeks) in a few selected areas (Bahir Dar, Adama etc.) where cases of COVID-19 were detected. This considerably affected consumers' behaviour in these towns, resulting in bulk purchases by urban dwellers after the lockdowns. This in turn increased local prices. The data from Fogera plain indicates that the price of paddy increased by an average of about 20 per cent and milled rice increased by about 21 per cent on average.

- Control of the movement of goods and prices: in an effort to control price increases, the government introduced a control mechanism through command posts (a sort of taskforce) at different administrative levels. The main target was to avoid product hoarding and the setting of inflated prices for goods. The rapid assessment made in the Fogera plain indicates that no measure has yet been taken in relation to rice product movement and price control. However, a number of retailers (Kiosk owners) selling diverse food items including rice in Addis Ababa have lost their license due to setting inflated prices.

- Reduced public services: due to COVID-19, there is a public measure which requires public offices to operate using half the normal number of staff, reducing the extent of services provided to stakeholders, including rice value chain actors. The period from March to June is normally the time to start preparing for planting, when input distribution is required (seed and fertiliser) and training is provided by extension workers. There has been due attention by the government at all levels to ensure the timely distribution of seed and fertiliser, including for rice production. Overall, the distribution of required inputs has not been too affected by COVID-19, as a result of the leading public input distribution systems. However, agricultural extension services, especially the provision of training as part of the extension packages, were disrupted due to the restrictions against assembling. The extension workers were also not provided with required COVID-19 preventive materials.

\subsection{Response to and the impact of COVID-19 on rice value chain actors}

The impact of COVID-19 emanates from the responses of the different actors in the rice value chain to the public measures put in place, the domestic and international market information, and the actors' business strategies in an effort to maximise their benefits from the pandemic.

- Smallholder rice producers: since the start of the COVID-19 pandemic, after the harvest from the 2018/19 rice production season, farmers' rice production processes have not been too affected. Rather, they have enjoyed higher prices, which 
Table 9.1 Monthly average price trends of paddy and milled rice in Birr/kg (2019 vs 2020)

\begin{tabular}{|l|l|l|l|l|l|l|l|}
\hline Actor & Type & Year & January & February & March & April & May \\
\hline \multirow{3}{*}{ Farmers } & \multirow{2}{*}{ Paddy } & 2019 & 10.34 & 10.82 & 10.82 & 10.82 & 11.14 \\
\cline { 3 - 8 } & & 2020 & 10.82 & 11.61 & 12.09 & 14.00 & 13.36 \\
\cline { 3 - 8 } & & \% increase & 4.64 & 7.30 & 11.74 & 29.39 & 19.93 \\
\hline \multirow{3}{*}{ Processors } & \multirow{2}{*}{ Milled rice } & 2019 & 16.25 & 17.00 & 17.00 & 17.00 & 17.50 \\
\cline { 3 - 8 } & & 2020 & 17.00 & 18.25 & 19.00 & 22.00 & 21.00 \\
\cline { 3 - 8 } & & \% increase & 4.62 & 7.35 & 11.76 & 29.41 & 20.00 \\
\hline
\end{tabular}

Source: Wereta city administration, Office of Trade and Market Development

increased on average by 5.67 per cent every month from January to May 2020 and by 14.72 per cent compared to average prices between January and May in 2019 (Table 9.1). The assessment indicated that farmers have been hoarding paddy rice, expecting further increases in price. Thus, the marketing practices of smallholder rice farmers have not been affected by COVID-19. However, the impact of COVID-19 on smallholder rice farmers' is expected to be felt in the following rice production season (2020/21), when shortages of hired labour are expected due to labour mobility restrictions and/or expected increases in daily wages, as well as limitations in the provision of adequate extension services. Those rice farmers who during the off season engage in producing vegetables that are not consumed locally, like cucumber, tomato, cabbage, and watermelons, have been highly affected. This is due to the lack of a market, as their main customers - hotels, restaurants, and institutional purchasers (universities and colleges) stopped purchasing.

- Collectors and farmer traders: the assessment indicated that these actors have been seriously affected and have lost revenue as smallholder farmers' supply to the market has considerably decreased due to the expectation of better prices in the coming months.

- Rice processors: the response of rice processors to the COVID-19 pandemic has seen a change in their strategy of provision of processing services and marketing milled rice. Due to the expectation of price increases, as a result of increased demand from consumers in response to lockdowns and the expected reduction in the volume of imported rice, processors have changed their commercial behaviour. Rice processors have limited their processing service provision, and instead they have been purchasing paddy and storing it in private storehouses. Paddy rice can be stored for longer periods without any pest damage compared to milled rice. They have adopted a piecemeal approach to processing, only processing a certain volume of their own paddy depending on price trends. Before COVID-19, processors provided farmers with free processing services. Farmers negotiate and agree prices per unit of volume of milled rice and agree that the by-products (broken rice, bran, and husk) are considered as compensation for the processing services. This market relationship was reported to be the main disincentive for quality rice processing as the more poorly the rice is processed, the more broken rice and bran the processor gets, which can be later processed as rice flour and sold to consumers for ingera (Assaye and Alemu 2020). Milled rice showed an average monthly price increase of 14.63 per cent from January to May 2020 (Table 9.1).

- Wholesalers: as purchase price increases have been transferred to the price at which the retailers and consumers buy rice, the effect of COVID-19 has been reported to be less in general than the impacts for farmers and processors.

- Importers: Ethiopia imports both semi-milled or wholly milled rice and broken rice, mainly from India and Pakistan, and to some extent from Vietnam. These countries introduced full export bans on rice in 2020, in an effort to contain the impact of the COVID-19 pandemic (Sulser and Dunston 2020). Ethiopian importers have continued to ship rice that was already purchased and/or for which the contracts had previously been signed. Accordingly, the volume of rice imports from January to March 2020 was more or less the same as the volume of imports in the same months in 2019. The data indicates that the volume of rice imported in January declined from about 36,000t in 2019 to 29,000t in 2020, whereas it increased in February from about 28,000t in 2019 to 43,000 t in 2020. However, the volume decreased in the month of March from about 36,000t in 2019 to about 25,000t in 2020 (Figure 9.1).

The information about the rice export ban in India and Pakistan is one of the major reasons for the change in market behaviour of most of the rice value chain actors. Farmers and processors attempted to hoard their produce until the effects of the export bans were realised. Thus, it is highly probable that the domestic price of rice will increase considerably, 
Figure 9.1 Trends in rice import



Source: Based on data from the Ethiopian Ministry of Revenues

given the very low level of self-sufficiency in rice. It is estimated that only about 30 per cent of the total rice consumed comes from domestic production.

- Public sector response: recognising the strategic importance of rice and expected challenges due to the COVID-19 pandemic, the MoA is designing intervention options to boost domestic production and productivity. This includes the expansion of rice production in the lowlands of the country, where there is huge potential for irrigated agriculture.

\subsection{The implications of rice value chain actors" response to COVID-19}

Overall, the implications of the responses of rice value chain actors to COVID-19 have mainly been reflected in increased prices and gradual reductions in the volume of paddy and milled rice supplied to the market. This directly affects the consumers, but rice producers and processors have been exploiting the opportunity to increase their incomes. This is mainly due to the fact that the COVID-19 pandemic started after farmers had harvested and threshed their rice from the 2018/19 season. However, it is expected that rice production and marketing will be seriously affected in the coming seasons, mainly due to the challenges related to the timely availability of required inputs (seed, fertiliser, and agro-chemicals) and the availability of hired labour, given the labour intensive nature of rice production. The limited possibilities for importing rice due to the export bans announced in the major rice exporting countries has also aggravated price increases and the local availability of rice. 
The political economy of the commercialisation of the rice value chain in Ethiopia is examined in this paper by considering the political importance of rice, the role and interest of rice value chain actors and their contribution to social inclusion, the role of development partners' to rice sector development, and the ongoing discourse related to the promotion of rice value chain in the country. The importance of the COVID-19 pandemic, the responses of rice value chain actors to the pandemic, and the implications of these responses for the rice value chain were also assessed. Based on the qualitative analysis of primary and secondary data in this paper, the conclusion highlights the key challenges and successes in the development of the rice value chain. It also identifies the unresolved areas of debate that need to be addressed to successfully commercialise Ethiopia's rice sector.

The expansion of rice production and its commercialisation was mainly linked to private incentives. However, the trends in terms of increased production, importation, and consumption of rice have received due attention from the government and development partners since 2010, when the National Rice Research and Development Strategy was approved.

The rice value chain in Ethiopia has evolved considerably in terms of the number and diversity of actors engaged. This has enhanced the contribution of the rice sector to the country's economy, as well as introducing associated challenges. The growth of the rice sector has led to the need to specifically govern rice research and development trends. Accordingly, a National Rice Research and Development Steering Committee, supported by the National Rice Secretariat and the National Rice Technical Committee was established in 2010 at the federal level. The main role of the Steering Committee is evaluating the progress of the rice sector, along with addressing emerging challenges based on the regular monitoring and evaluation activities undertaken by the Technical Committee and the Secretariat.

In terms of enhancing social inclusion, increased rice commercialisation plays an important role by improving youth employment, both at rice production and processing levels. This is achieved through (i) direct engagement in rice production with the public land allocation measures for landless youth families; (ii) casual and permanent employment opportunities created to support the different rice farm operations at smallholder rice farms, as well as the different activities at rice processing facilities; and (iii) job opportunities created by the different emerging businesses from the spill over effects of rice commercialisation, including hospitality and tourism, banking, fuel stations, other processing industries, and smaller businesses. The emergence and expansion of small businesses managed by mainly women, like restaurants, coffee houses, and kiosks, has contributed tremendously to empowering women to earn their own livelihoods and creating job opportunities for others.

With support from international research organisations, specifically AfricaRice and IRRI, the national research system has managed the release of a number of rice varieties with associated agronomic practices. However, due to the weak national seed system, mainly linked to limited commercial interest from both public and private seed companies, the adoption and replacement rate of available varieties is still low. Farmers still widely use the initially introduced variety called $X$-Jigna.

The mechanisation of rice production in Ethiopia is very low. This is despite the government's provision of a number of incentives to promote mechanisation, mainly in terms of allowing tax-free importation of agricultural machineries and tools.

As indicated, in the Ethiopian context, rice processors play a pivotal role in the rice value chain. Most rice processors are traditional and have shifted from grain milling to rice processing (or they still operate both), using very old machines. The operation and maintenance activities of processors are learnt through trial and error. There are currently no private or public organisations that provide certified training and formal licensing for machine operation and maintenance. It is planned that the NRRTC will be equipped with required facilities and develop a curriculum to start providing processors with formal training. In this regard, the role of development partners is expected to be high, mainly because the strategy is to adapt available technologies and innovations from elsewhere in the world. It is also through development partners' support that rice was 
introduced and has been promoted in the country since the late 1970s.

In an effort to enhance the commercialisation of rice, along with its contribution to the agricultural sector, the key areas currently debated are:

i) How to ensure national rice self-sufficiency. Rice has become one of the major imported agricultural commodities alongside wheat, costing the country's meagre foreign currency reserve, which reached more than US\$250 million in 2019. Accordingly, the government has decided to invest in the rice sector and an overall plan of action, starting from the 2020 production season, is under preparation.

ii) The role of smallholder rice farmers and commercial farms has been debated. Initially, the government direction was to promote commercial rice farming with incentives, such as early access to land and tax holidays. The government aimed to export 100 per cent of commercial produce to avoid competition with smallholder farmers in the domestic market. However, recent directions indicate the permission of commercial rice farms to sell domestically to support import substitution. Some of the earlier big investments in rice farming and processing have not yet succeeded as expected. It is important to review the challenges faced by these interventions and address them accordingly.

iii) Rice processors are the pivotal actors in the rice value chain and their performance determines the overall efficiency of the rice value chain. Thus, the need for the professionalisation and standardisation of the rice processing industry is well recognised. However, the best way to implement this is still debated and is considered a key challenge that needs due attention.

iv) So far, the expansion of rice production has been in areas that have avoided significantly replacing the production of other crops, mainly in Fogera plain. However, due to the expansion of rice in the upland areas of the country, linked to the release of upland rice varieties, there is debate about the implications of the expansion of rice to replace other crops and livestock. This challenge needs to be further examined, especially to ensure proper land and soil management, along with crop rotations, for the sustainability of rice production systems.

v) Given the specific nature of rice, particularly its high labour demand and mandatory value addition (processing), there is a need to facilitate the creation of job opportunities and women's empowerment.

vi) Official national rice statistics have been a point of discussion, given the availability of different figures in terms of the number of farmers engaged in rice production, the area covered, and productivity achieved, from different sources. It is important that a rice specific national survey is developed to set the base data and to properly design/revise rice related strategies.

With the declaration of COVID-19 as a pandemic and its incidence in Ethiopia in early March 2020, the different measures put in place by the government have prompted diverse responses and expectations from actors in the rice value chain. The responses of these actors, especially farmers and processors, have resulted in a gradual increase in the prices of domestic and imported rice. The price increases have positively affected farmers and processors in the short term, as the COVID-19 pandemic started after the farmers had harvested and threshed. However, it has been negatively affecting consumers. In the coming months, it is also expected that prices will be even higher, given the export bans on rice by exporting countries. The production of rice in the next season is also expected to be affected. Thus, it will be important to properly plan to expand rice production, not only to the lowland areas with access to irrigation but also in the current rice producing hubs, by ensuring the engagement of all value chain actors, especially rice processors. Previous attempts to expand rice production have indicated that the limited readiness of processors to ensure timely processing seriously disincentivised farmers from engaging in rice production in the subsequent season. The initiated plan of action, thus, needs to be comprehensive enough to consider the diverse and specific needs of rice. It is also important to disincentivise the hoarding of paddy rice, especially by processors, through awareness creation and regulatory measures. 
AfricaRice (2018) Continental Investment Plan for Accelerating Rice Self-Sufficiency in Africa (CiPRiSSA), Abidjan: Africa Rice Center

AgroBIG II (2018) Programme for Agro-Business Induced Growth in the Amhara National Regional State Second Phase, Addis Ababa: Ministry of Finance and Economic Cooperation: Ethiopia and Helsinki: Ministry for Foreign Affairs.

Alemu D. and Berhanu, K. (2018) The Political Economy of Agricultural Commercialisation in Ethiopia: Discourses, Actors and Structural Impediments, APRA Working Paper 14, Brighton: Future Agricultures Consortium

Alemu, D. and Thompson, J. (2020) The Emerging Importance of Rice as a Strategic Crop in Ethiopia, Working Paper 44, Brighton: Future Agricultures Consortium

Alemu, D.; Tesfaye, A. and Assaye, A. (2018) A Historical Analysis of Rice Commercialisation in Ethiopia: The Case of the Fogera Plain, APRA Working Paper 18, Brighton: Future Agricultures Consortium

Assaye, A. and Alemu, D. (2020) Enhancing Production of Quality Rice in Ethiopia: Dis/incentives for Rice Processors, APRA Policy Brief 22, Brighton: Future Agricultures Consortium

Awulachew S.B.; Erkossa, T. and Namaram, R.E. (2010) Irrigation Potential in Ethiopia: Constraints and Opportunities for Enhancing the System, Addis Ababa: International Water Management Institute

Ayana, A. and Alemu, D. (2019) 'Rice Seed System in Ethiopia' in T. Tadesse et al. (eds.), Advances in Rice Research and Development in Ethiopia, Ethiopian Institute of Agricultural Research

Benin, S. et al. (2020) Political Economy of National Agricultural Statistics: The Case of Niger, IFPRI Discussion Paper 01929, Washington, DC: International Food Policy Research Institute

Crisan, E., Parpucea, I. and llies, L. (2011) 'The Relation Between Supply Chain Performance and Supply Chain Governance Practices', Management \& Marketing Challenges for the Knowledge Society 6(4): 637-644

CSA (2019) Report on Area and Production of Major Crops (Private Peasant Holdings, Meher Season), Agricultural Sample Survey 2018/19, Volume I, Statistical Bulletin 589, Addis Ababa: Central Statistical Agency

CSA (2018) Report on Area and Production of Major Crops (Private Peasant Holdings, Meher Season), Agricultural Sample Survey 2017/18 Volume I. Statistical Bulletin 586, Addis Ababa: Central Statistical Agency

Deininger K., Zevenbergen, J. and Ayalew D. (2006) 'Assessing the Certification Process of Ethiopia's Rural Lands', paper presented at Colloque International "Les Frontières de la Question Foncière - At the Frontier of Land Issues", Montpellier, 2006

Deininger K. et al. (2003) Market and Nonmarket Transfers of Land in Ethiopia: Implications for Efficiency, Equity, and Nonfarm Development, Policy Research Working Paper 2992, Washington, DC: World Bank

Gereffi G.; Humphrey J. and Sturgeon T. (2005) 'The Governance of Global Value Chains', Review of International Political Economy, 12(1): 78-104

Getnet B.; Alebachew M. and Ageze M. (2019) 'Research on Pre-Harvest Technologies for Rice Production in Ethiopia' in T. Tadesse et al. (eds.), Advances in Rice Research and Development in Ethiopia, Addis Ababa: Ethiopian Institute of Agricultural Research

Getnet B., Lema Y., Alebachew M. (2019) 'Post-Harvest Processes and Advances to Introduce Loss Reducing 
Technologies for Rice' in T. Tadesse et al. (eds.), Advances in Rice Research and Development in Ethiopia, Addis Ababa: Ethiopian Institute of Agricultural Research

GRiSP (Global Rice Science Partnership) (2013) Rice Almanac, 4th Edition. Los Baños: International Rice Research Institute

Hostetter L. (2011) 'Ethiopians Driving Growth Through Entrepreneurship and Trade Project: Overview of its Rice Related Activities' in K. Assefa et al. (eds.), Challenges and Opportunities of Rice in Ethiopian Agricultural Development, Empowering Farmers' Innovation Series No. 2: 53-61

Ismail, A. (2019) 'Towards Rice Self-sufficiency in Africa' in T. Tadesse et al. (eds.) Advances in Rice Research and Development in Ethiopia, Addis Ababa: Ethiopian Institute of Agricultural Research

MoA (2015) Agriculture Sector Growth and Transformation Plan II (2015-2020), Addis Ababa: Ministry of Agriculture

MoA (2018) Crop Variety Register. Issue No. 21. Plant Variety Release, Protection and Seed Quality Control Directorate, Addis Ababa: Ministry Of Agriculture

MoA (2019) Transforming the Ethiopian Seed Sector: Issues and Strategies. Ministry of Agriculture, Addis Ababa, Ethiopia

MoA (2020) National Rice Development Strategy-II (2020 -2030), Addis Ababa: Ministry of Agriculture

MoARD (2010) National Rice Research and Development Strategy of Ethiopia, Addis Ababa: Ministry of Agriculture and Rural Development

Roy-Macauley, H. (2019) 'Rice Research for Development in Africa: Experience from AfricaRice' in T. Tadesse et al. (eds.), Advances in Rice Research and Development in Ethiopia, Addis Ababa: Ethiopian Institute of Agricultural Research

Shiratori, K. (2019) 'EthioRice Project for Enhancing Fogera Rice Research and Training Center' in T. Tadesse et al. (eds.), Advances in Rice Research and Development in Ethiopia, Addis Ababa: Ethiopian Institute of Agricultural Research

Sulser, T. and Dunston, S. (2020) 'COVID-19-Related Trade Restrictions on Rice and Wheat Could Drive Up Prices and Increase Hunger', 15 May, IFPRI blog, https://www.ifpri.org/blog/covid-19-related-trade-restrictions-rice-andwheat-could-drive-prices-and-increase-hunger (accessed 9 June 2020)

Taddesse, T.; Alemu, D. and Assaye, A. (2020) The White Gold of Wereta: A City Raised on Rice, APRA Policy Brief 24, Brighton: Future Agricultures Consortium

Tadesse, T. (2019) 'Status and Directions of Rice Research in Ethiopia' in T. Tadesse et al. (eds.), Advances in Rice Research and Development in Ethiopia, Addis Ababa: Ethiopian Institute of Agricultural Research

Watabaji, M.; Molnar, A. and Gellynck, X. (2016) 'Integrative Role of Value Chain Governance: Evidence from the Malt Barley Value Chain in Ethiopia', Journal of the Institute of Brewing, 122(4): 670-681

Woperies, M. et al. (eds.) (2013) Realizing Africa's Rice Promise, Wallingford: CAB International

Yimer, M. (2019) 'Experiences of MEDA in Rice Promotion in South Gondar Zone' in T. Tadesse et al. (eds.) Advances in Rice Research and Development in Ethiopia, Addis Ababa: Ethiopian Institute of Agricultural Research 


\section{ENDNOTES}

1 Categories are as per the tax classifications in Ethiopia: $A=$ investment greater than 1 million Birr (US $\$ 30,300)$, $\mathrm{B}=$ investment ranging from $0.5-1$ million Birr (US\$15,150-US\$30,300), and $\mathrm{C}=$ investment less than 0.5 million Birr $($ US $\$ 15,150)$ 
Alemu, D. and Assaye, A. (2021) The Political Economy of the Rice Value Chain In Ethiopia: Actors, Performance, and Discourses, APRA Working Paper 51, Brighton: Future Agricultures Consortium

(c) APRA 2021

ISBN: 978-1-78118-774-6

https://doi.org/10.19088/APRA.2021.004

\section{(cc) BY-NC-ND}

This is an Open Access report distributed under the terms of the Attribution-Non Commercial-No Derivs 4.0 Unported (CC BY-NC-ND 4.0) Attribution - You must give appropriate credit, provide a link to the license, and indicate if changes were made. You may do so in any reasonable manner, but not in any way that suggests the licensor endorses you or your use. NonCommercial — You may not use the material for commercial purposes. NoDerivatives - If you remix, transform, or build upon the material, you may not distribute the modified material. You are free to: Share - copy and redistribute the material in any medium or format.

https://creativecommons.org/licenses/by-nc-nd/4.0/legalcode

If you use the work, we ask that you reference the APRA website (www.future-agricultures.org/apra/) and send a copy of the work or a link to its use online to the following address for our archive: APRA, Future Agricultures Consortium, University of Sussex,

Brighton BN1 9RE, UK (apra@ids.ac.uk)

All APRA Working Papers go through a review process before publication.

(c) creative

\section{DO YOU HAVE COMMENTS ON THIS PAPER?}

We would welcome your feedback on this working paper!

To provide brief comments, please follow this link to our short APRA Working Paper Feedback form: https://goo.gl/forms/1iVnXhhrlGesfR9

Agricultural Policy Research in Africa (APRA) is a programme of the Future Agricultures Consortium (FAC) which is

generating new evidence and policy-relevant insights on more inclusive pathways to agricultural commercialisation in sub-Saharan Africa. APRA is funded with UK aid from the UK Foreign, Commonwealth \&

Development Office (FCDO) and will run from 2016-2022.

The APRA Directorate is based at IDS, UK (www.ids.ac.uk), with regional hubs at the Centre for African Bio-Entrepreneurship (CABE), Kenya, the Institute for Poverty, Land and Agrarian Studies (PLAAS), South Africa, and the University of Ghana, Legon. It builds on more than a decade of research and policy engagement work by the Future Agricultures Consortium (www.future-agricultures.org) and involves more than 100 researchers and communications professionals in Africa, UK, Sweden and USA.

Funded by
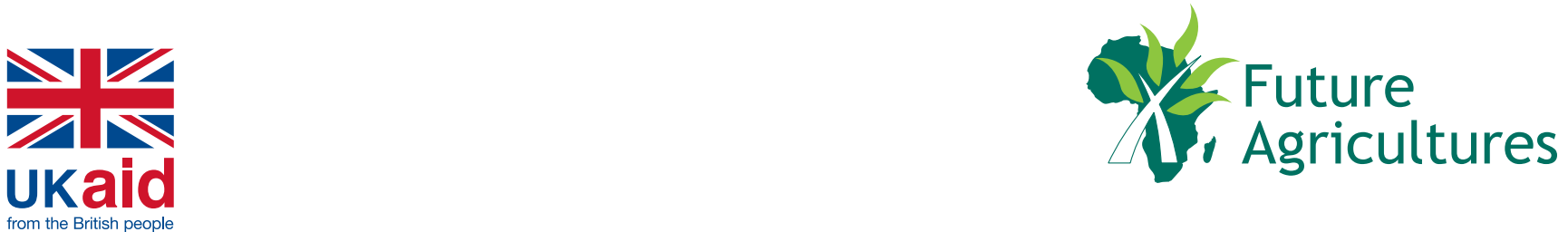